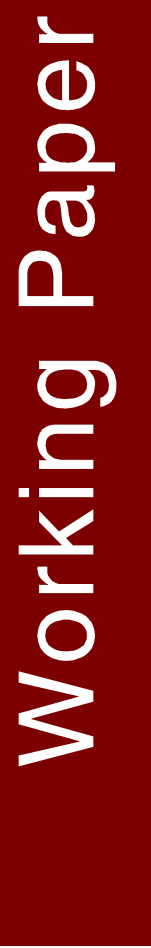

Stewardship agreement to reduce emissions from deforestation and degradation (REDD): Lubuk Beringin's hutan desa as the first village forest in Indonesia

Ratna A kiefnawati, Grace B Villamor, Farid Zulfikar, Iman Budisetiawan, Elok Mulyoutami, Asep Ayat and Meine van Noordwijk 



\title{
Stewardship agreement to reduce emissions from deforestation and degradation (REDD): Lubuk Beringin's hutan desa as the first village forest in Indonesia
}

\author{
Ratna Akiefnawati ${ }^{1}$, Grace B Villamor ${ }^{2}$, Farid Zulfikar ${ }^{3}$, Iman Budisetiawan ${ }^{4}$, \\ Elok Mulyoutami $i^{5}$, Asep Ayat ${ }^{6}$ and Meine van Noordwijk
}

Working Papernr 102

\footnotetext{
${ }^{1}$ World Agroforestry Centre (ICRAF) Southeast Asia, Jl. CIFOR, Situ Gede, Sindang Barang Jero, Bogor, Indonesia Email: r.akiefnawati@cgiar.org

${ }^{2}$ World Agroforestry Centre (ICRAF) Southeast Asia, JI. CIFOR, Situ Gede, Sindang Barang Jero, Bogor, Indonesia Email: gracev@uni-bonn.de

${ }^{3}$ KKI-WARSI, JI. Inu Kertapati, Jambi, Indonesia. Email: fazul_restor@yahoo.com

${ }^{4}$ Dinas Kehutanan dan Perkebunan, Kabupaten Bungo, Jambi. Jl. RM Taher, Muara Bungo, Jambi, Indonesia Email: iman_budisetiawan@yahoo.com

${ }^{5}$ World Agroforestry Centre (ICRAF) Southeast Asia, Jl. CIFOR, Situ Gede, Sindang Barang Jero, Bogor, Indonesia Email: e.mulyoutami@cgiar.org

${ }^{6}$ World Agroforestry Centre (ICRAF) Southeast Asia, Jl. CIFOR, Situ Gede, Sindang Barang Jero, Bogor, Indonesia Email: a.ayat@cgiar.org

${ }^{7}$ World Agroforestry Centre (ICRAF) Southeast Asia, Jl. CIFOR, Situ Gede, Sindang Barang Jero, Bogor, Indonesia Email: m.vannoordwijk@cgiar.org
} 


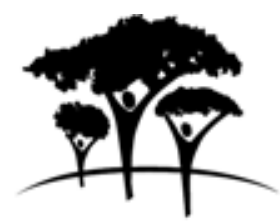

World Agroforestry Centre

TRANSFORMING LIVES AND LANDSCAPES

\section{Correct citation:}

Ratna Akiefnawati, Grace B Villamor, Farid Zulfikar, Iman Budisetiawan, Elok Mulyoutami, Asep Ayat and Meine van Noordwijk. 2010 Stewardship agreement to reduce emissions from deforestation and degradation (REDD): Lubuk Beringin's hutan desa as the first village forest in Indonesia. Working paper nr 102. World Agroforestry Centre. Bogor, Indonesia. 39p

Titles in the Working Paper Series aim to disseminate interim results on agroforestry research and practices and stimulate feedback from the scientific community. Other publication series from the World Agroforestry Centre include: Agroforestry Perspectives, Technical Manuals and Occasional Papers.

Published by

World Agroforestry Centre

ICRAF Southeast Asia Regional Office

PO Box 161, Bogor 16001, Indonesia

Tel: +62 2518625415

Fax: +62 2518625416

Email: icraf-indonesia@cgiar.org

http://www.worldagroforestrycentre.org/sea

(C) World Agroforestry Centre 2010

Working Paper nr 102

The views expressed in this publication are those of the author(s) and not necessarily those of the World Agroforestry Centre.

Articles appearing in this publication may be quoted or reproduced without charge, provided the source is acknowledged.

All images remain the sole property of their source and may not be used for any purpose without written permission of the source. 


\section{Summary}

Contested rules between the state and local communities over the use and protection of forests are a threat to Indonesia's forests, environmental services and livelihoods. Success in forest protection and reducing emission from deforestation and degradation (REDD) requires conflict resolution. The recent village forest (Hutan Desa) regulation by the Minister of Forestry (P.49/Menhut-II/2008) details how to reconcile forest management targets and livelihood interests of forest-edge villages within the framework of a permanent forest estate. Lubuk Beringin in Bungo district, Jambi Province, Sumatra, became the first village in Indonesia to secure such an agreement. Our analysis of the process, stakes and social capital that bridged local, district and national levels for the Hutan Desa agreement aims to help in reducing transaction costs for wider application as part of any REDD schemes, identifies locally appropriate mitigation action as part of national strategies and examines co-investment in stewardship for local, national and global benefits.

\section{Keywords}

Action research, Community Forest Management, Hutan Desa, REDD+, village forest
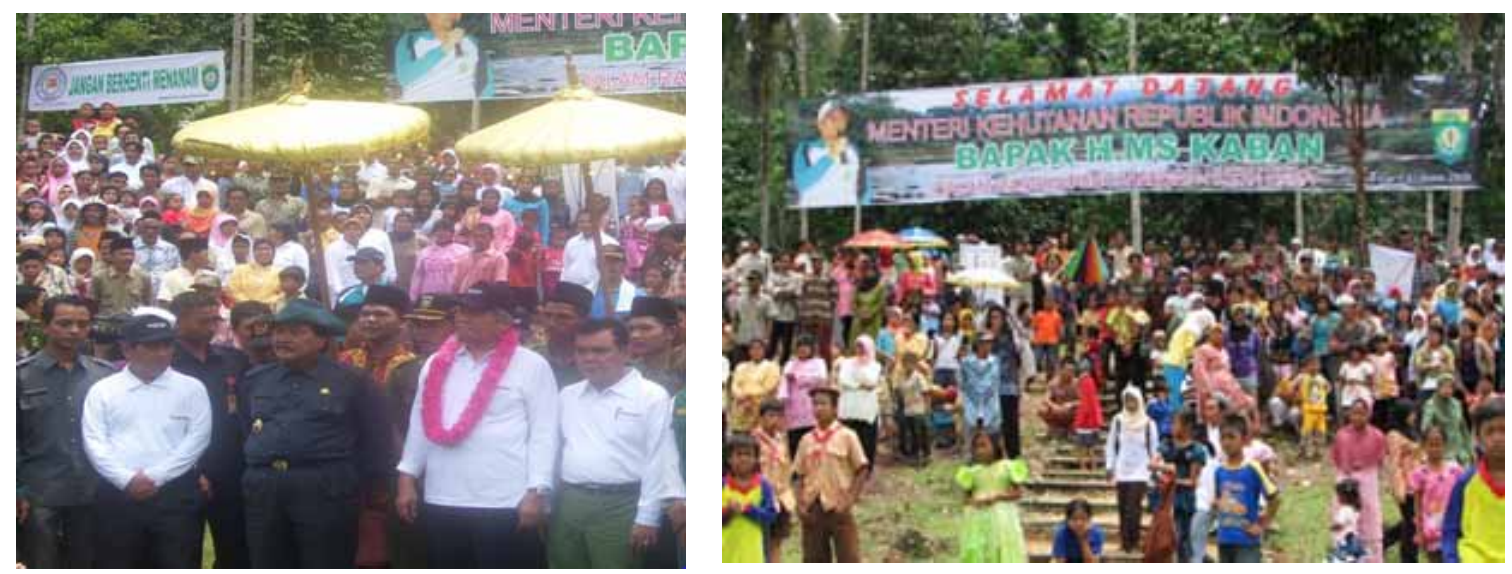


\section{Acknowledgement}

The activities of the World Agroforestry Centre (ICRAF) and KKI-WARSI that facilitated the process were funded through the Swiss Development Cooperation (SDC) and International Fund for Agricultural Development (IFAD). Comments by Retno Maryani, Peter Minang, Gamma Galudra, Suyanto, Laura German and Jess Fernandez on an earlier draft improved the manuscript. 


\section{Contents}

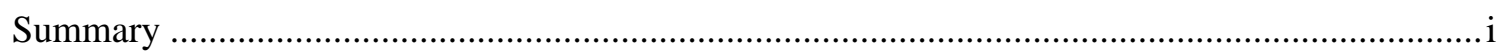

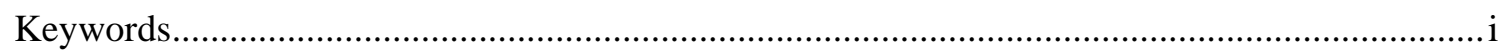

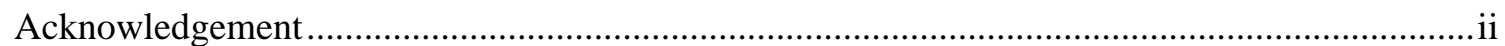

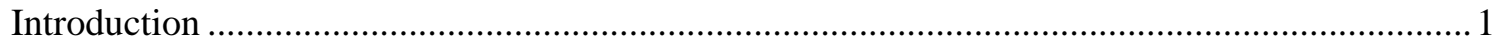

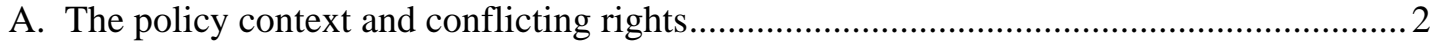

B. Lubuk Beringin: Forest-village gradient and social capital ............................................ 4

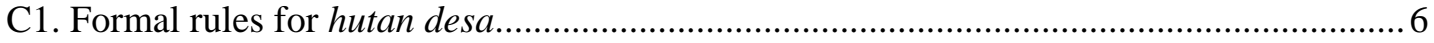

C2. Obtaining hutan desa recognition for Lubuk Beringin ................................................... 8

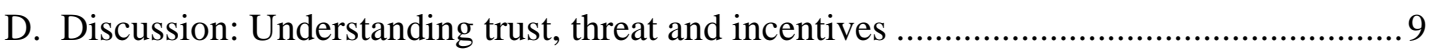

Community coherence and connectedness ................................................................ 9

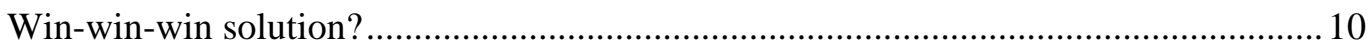

E. Relevance for the international redd debate …............................................................. 12

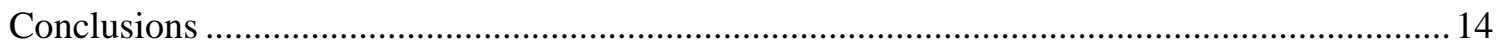

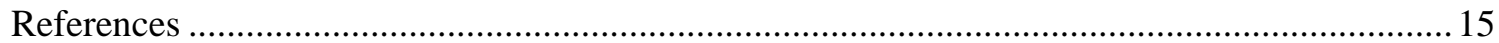




\section{Introduction}

Reducing Emissions from Deforestation and Degradation (REDD) is a concept that has goals and clear performance criterion. Reductions can be achieved in multiple ways. Much of the public debate has focussed on financial incentives as the core of REDD policies (Angelsen and others 2009, Stern 2008, Verchot and Petkova 2009). Expectations of financial gain have created interest among many of the policy and governance players involved but have also created conflicts and an array of bargaining positions.

At the root of continuing deforestation and degradation is a lack of legal clarity about rights, with accompanying conflicting points of view. Fighting over financial benefits may make matters worse rather than better. Clarifying rights and resolving conflicts can make it much cheaper to change the land-use in any particular landscape. This should then become an important part of a national REDD strategy.

Debate about REDD focuses on two main arguments: efficiency and fairness (Suyanto et al. 2009). The argument for efficiency looks at the current threats to achieving reductions in emission and the various parties' bargaining positions, with a tendency to focus on financial benefits. The argument for fairness focuses on medium-to-long-term threats and the enhancement and maintenance of trust between the different people involved. There is more emphasis on investment in assets and the links between social, natural and financial capital.

REDD is often seen as a form of (or at least closely related to) Payments for Environmental Services (PES). Van Noordwijk and Leimona (2010) distinguished three paradigms within PES: (1) commoditisation of environmental services (for example, via carbon-offset and credit markets, payment on delivery); (2) compensation for opportunities skipped (for example, the forest maintenance payments in Costa Rica with weak conditionality) and; (3) co-investment in stewardship (for example, investing across multiple types of capital, sharing risk and responsibility).

The first two paradigms require clarity of property rights at the start of the process, assessment of the legality of activities that threaten environmental services and enforcement of laws that set minimum standards of behaviour. The third paradigm is feasible where any of the preconditions of the first and second paradigms are not met. Van Noordwijk and Leimona, in the work cited above, claim that the opportunities for co-investment in stewardship are therefore much more widespread than those for the other two paradigms. A historical analysis of the PES concept (Gomez-Baggethun and others 2010) leads to a similar conclusion. Coinvestment in stewardship also fits with German and Keeler's (2010) analysis of "hybrid" institutions (combining formal and informal groups and structures), which can be more successful with seemingly unsolvable natural resource management challenges at farm and landscape levels.

A case study of conflict resolution for a Hutan Desa agreement is described here as a lowcost, but essential, precursor for REDD schemes. Indonesia is not only the leader in terrestrial carbon emission, it is also the leader in commitment to Nationally Appropriate Mitigation Action (NAMA) as the basis for building global trust and achieving international cooperation to manage climate change. As mentioned above, the Hutan Desa agreement was helped by 
expectations of REDD benefits flowing to government agencies that have a veto on forest agreements. These agencies had little interest in supporting any agreements before REDD entered the debate.

The paper will start with a description of the rules and associated conflicts over planning and control of forests in Indonesia (section A), followed by an account of the Lubuk Beringin village (section $\mathrm{B}$ ). The emergence of new rules for reconciling the interests of such a village with those of national forest authorities in the form of Hutan Desa is then presented (section C), along with the process that had to be followed to obtain the first permit. Then, (section D) the emergence of the Hutan Desa agreement for Lubuk Beringin is discussed in the context of trust, threats and incentives (for example, what pre-disposed Lubuk Beringin to become a pioneer forest village? How difficult will it be to expand the process to secure more agreements?), followed by considerations of the relevance of this case for the global REDD debate (section E).

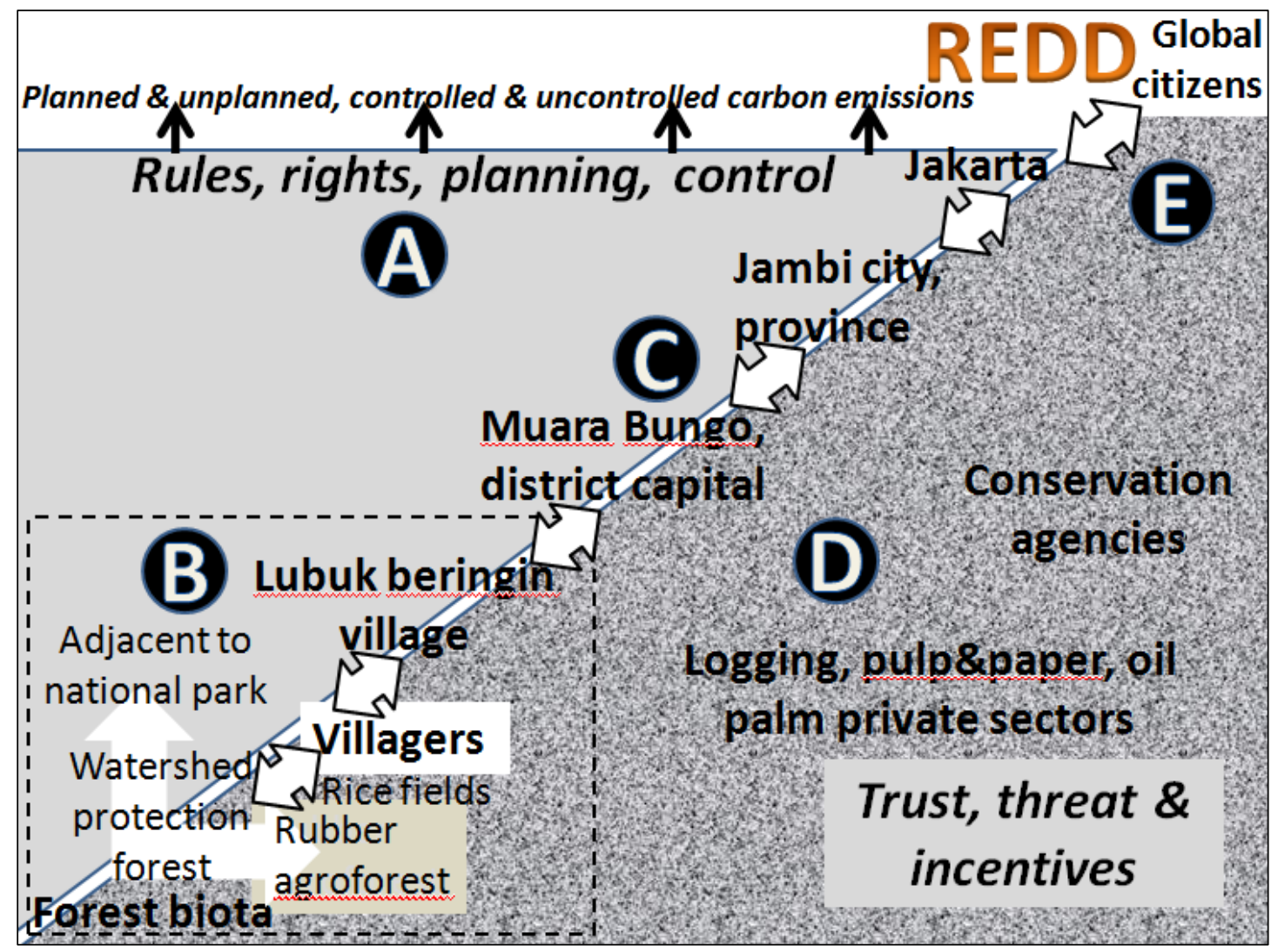

Figure 1. Schematic representation of the cross-level relations between a specific forest-village gradient, nested in a regency (district), province, country and global network of relations that can be understood formally (rules, rights and planning; upper triangle) and informally (trust, threat and incentives; lower triangle). (Note: Letters A to E are the sections of this paper).

\section{A. The policy context and conflicting rights}

In Indonesia, as elsewhere, the right to use, manage and/or destroy natural forest is, by the constitution, vested in the state for the benefit of the people. In practice, the opinions of the state and local communities on how such benefits should be allocated have differed over time (Fay and Michon 2005). The historical basis of the state's claim over all natural resources 
varies within Indonesia because of the patchwork of governance arrangements and agreements with local rulers that the colonial government left behind (Galudra and Sirait 2009). Jambi province, Sumatra, was only brought under colonial rule in 1908 when nearly all land accessible by river, which was the major means of transport, was already used for agriculture. Only land in the mountains (which later would become the Kerinci Seblat, Bukit Tigapuluh and Bukit Duabelas national parks) and peat swamp/mangrove zones became firmly established protection-forest zones. The remaining forests on the lowland peneplains, beyond the reach of villages at the time of colonial rule, were established as forest reserves. After Indonesia's independence, in the 1960s roads were built and those forests were assigned to logging concessions.

In the early 1990s, the Kerinci Seblat National Park, the largest protected area in Sumatra, was the target of what was supposed to become an exemplary Integrated Conservation and Development Project (ICDP) ${ }^{8}$. The project was closed in 2002, as evaluations suggested that its goals were not achieved. An impact study by Helmi and Yoariza (2002) compared villages that were involved in the project with those villages outside and concluded that the ICDP achieved the goal of conservation awareness but failed to match the rate of development through alternative livelihood options. Ironically, the ICDP failed at its core by the lack of integration, contrary to its name, and because it remained a project. The various service delivery sectors did not work together despite participatory mechanisms. There was no effective support for the villagers to guard the park when confronted with outsiders who intrude through their village, while conservation grant disbursement increased inequity and sparked jealousies. The failure of this ICDP is not unique. However, failure because of projectisation and poor implementation should not stop the search for real integration of conservation and development through other means (Pfundt et al. 2008). Local, national and global stakes in the outcome clearly need effective reconciliation.

While a fully rights-based approach was difficult in pre-1998 Indonesia with its absence of a universally accepted baseline and point of reference, agreements on the types of resource-use and associated benefit-sharing could be negotiated. Elsewhere in Sumatra, tenure security was achieved and started to have positive effects for both livelihoods and environmental services, but mutual agreement on the clarification of rights was not achieved (Kusters et al. 2007, Suyanto et al. 2005).

The 1998 political change in Indonesia altered the situation, though not necessarily the actors and stakes. The Indonesian Forestry Law No. 41 of 1999 contains a number of mechanisms including privately owned forest (Hutan Hak), recognition of traditional rights (Hutan Adat), community-based forest management (Hutan KeMasyarakatan or HKM) and village forest management (Hutan Desa). These mechanisms could be applied to forests that have permanent watershed protection status (Hutan Lindung) and forests that could be subjected to sustainable logging practices or severely degraded areas for forest plantation development (including Hutan Tanaman Rakyat or HTR). However, between the legal opportunity and a fully functional implementation program, many intermediate steps needed to be taken to align forest governance agencies at district, provincial and national levels. Until implementation rules were established, no forest had been formally designated as Hutan Desa.

${ }^{8}$ World Bank-sponsored project 
The 1999 forestry law was influenced by the decentralisation agenda of the 1998 Reformasi period in Indonesian politics. However, the mood in the forest sector rapidly swung back towards recentralization in 2002. According to Djogo and Syaf (2003)

... the decentralisation of forest resource management authority to local governments has resulted in a situation in which district governments are neither accountable upward to the central government nor downward to the local people. The decentralization of authority without appropriate devolution processes or control mechanisms has resulted in the decentralization of opportunistic behaviour that is in direct opposition to the development of good local forest governance. The delegation of authority has in fact resulted in the decentralization of power to the private sector.

Increasingly over the past decade, international concerns over the fate of tropical rainforests, driven by concerns for biodiversity as well as greenhouse gas emissions and climate change, focused on governance and the control of illegal logging. More direct involvement of local communities is widely seen as an important part of any solution. The discussion on REDD that started in Indonesia ahead of the Thirteenth Conference of Parties of the United Nation's Framework Convention on Climate Change in Bali in 2007 re-emphasised the need to reduce conflict over forest boundaries and engage local communities in forest management (IFCA 2007, van Noordwijk et al. 2008). Jambi province was keen to be one of the pioneers in emerging REDD programs and this provided support at provincial level for moving ahead with initiatives for local forest governance.

\section{B. Lubuk Beringin: Forest-village gradient and social capital}

Lubuk Beringin, with a total area of 2800 hectares (of which 84 percent is watershed protection forest), is one of the villages in Sub-District Bathin III Ulu, Bungo district, Jambi province. It is categorised as a poor village within the district, with below-average income levels. The village's main sources of food are its rice paddies. The main source of income is rubber and occasionally durian and other fruits obtained from the rubber agroforests that also provide medicinal plants. While technically feasible, the intensification of rubber gardens involves risks of failure and requires credit sources at discount rates, which are not locally available (Joshi et al. 2003, Williams et al 2001).

In 1997, the village became part of the ICDP-TNKS program which aimed to develop an agreement of village rules on environmental preservation. The agreement included maintaining forest areas; not cultivating land with more than 80 degree slope; and planting bamboo along the riverside to stop erosion and landslides.

Lubuk Beringin is part of the Rantaupandan valley. From here, the Rewarding Upland Poor for Environmental Services (RUPES) ${ }^{9}$ project of the World Agroforestry Centre (ICRAF) explored how rewards could be provided for environmental services in Bungo district after the closure of the ICDP. The project team included Lubuk Beringin as one of the focal villages, building on the social capital that had been achieved by the ICDP, but relying on local initiative. As the rubber agroforests of Lubuk Beringin border on, and are partly

${ }^{9}$ RUPES is a programme funded by the International Fund for Agricultural Development (IFAD). 
classified as, watershed protection forest (Hutan Lindung), the key issues for the village were their lack of tenure security and how to deal with external disturbance to the forest upstream. One of the RUPES sites had been successful in supporting and increasing the use of the community-based forest management procedures (HKM) of the forest law. A similar approach seemed appropriate for Lubuk Beringin. At central government level, however, the HKM option was seen as losing control, partly because the relationship between community groups and formal government is not clear, even at the lowest level.

RUPES activities in Bungo focused on options for “jungle” rubber or biodiversity-friendly rubber agroforest management (Kuncoro et al. 2006). These activities raised local awareness of the trade-offs involved in rubber intensification, that is, while rubber yields increase, the local public goods and services of the agroforest decline. The village discussed the relevance of protecting their existing rubber agroforestry systems. Rubber agroforests serve as fauna and flora habitat and can preserve watershed functions. Since the village was not yet connected to the electricity grid, the idea arose to use the local river as a source of hydropower. The RUPES project team supported the idea as a direct reward for environmental services and a way to increase incentives to villagers to protect the watershed. The local government later stepped in and provided further support when the first pilot project succeeded and the village had shown the ability to organise themselves. The village's efforts were further recognised in 2006 by gaining second place in the prestigious national Kalpataru award at provincial level and as the top candidate in 2007. With these nominations, the visibility of the village was amplified and its commitment to combine conservation and livelihood improvement was strengthened.

The Lubuk Beringin villagers have committed themselves to maintaining the Rantau Bayur protected forest area because the forest provides the water they need for drinking, generating electricity for their village and irrigating their rice fields. A village rule (PERDUS) guides their management of the water and their use of the forest both for timber and non-timber purposes. The rule forbids land clearing and villagers campaign for this by providing information in the mosque. The main threat to the forest, however, comes from the neighbouring villages and their development plans. These villages have agreements with private companies for oil palm development and implement local transmigration programs to increase their population size.
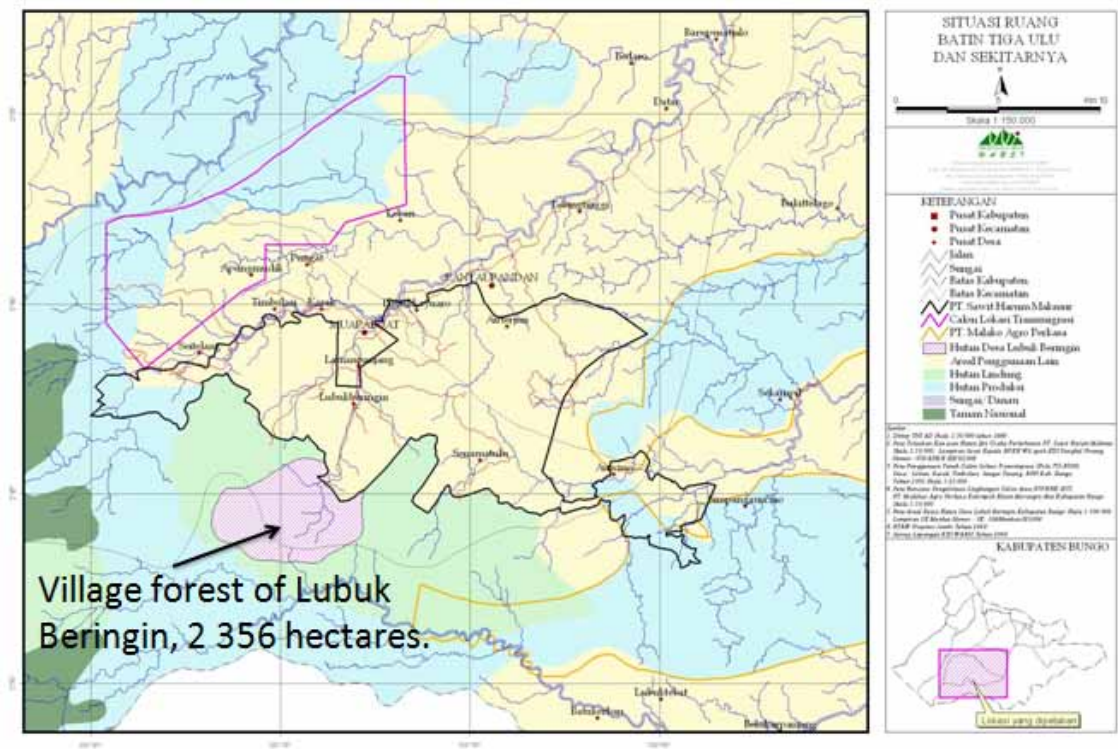


\section{C1. Formal rules for hutan desa}

Government rules No. 6 of 2007 and No. 3 of 2008 indicated that forest management needs to be based on empowering the community, developing local capacity and giving access in order to increase the prosperity of people living in or near the forest. The rules clarified village forest or Hutan Desa and community-based forest management.

Hutan Desa areas are part of the national forest estate managed by a village community through a local village organisation that plans, manages and allocates benefits derived from the forest. The management is not only focused on using forest resources but includes responsibilities to preserve the life-supporting functions of the forest. The procedure for assigning rights to any village in Indonesia involves approval at district, provincial and national levels (Figure 2). The Hutan Desa designation became operational under a decree from the Minister of Forestry No. P. 49/Menhut-II/2008 of 25 August, 2008.

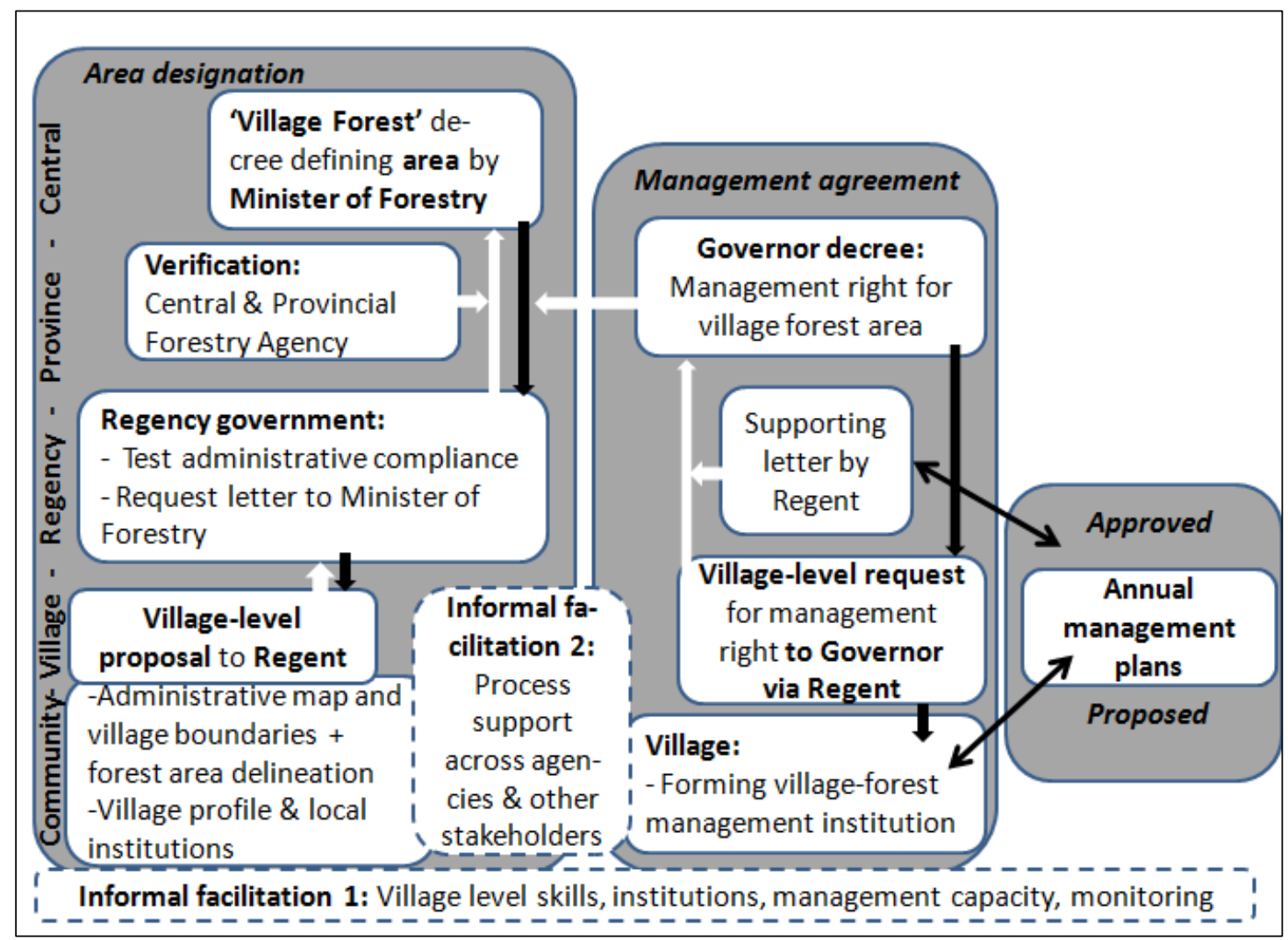

Figure 2: Process of obtaining a Hutan Desa designation, management rights and annual management plans for a village forest.

The area which can become Hutan Desa has to be administratively part of the village and can include watershed protection forest and production forest (as long as there are no existing concession rights). The permission period for Hutan Desa is 35 years and is renewable for another 35 years subject to approval of annual work plans. Detailed information about rights and obligations, work plans and other duties within the Hutan Desa scheme are presented in Table 1. 
Table 1: Specifications of Hutan Desa in Government Rule No. 6 of 2007 and Government Rule No. 3 of 2008.

\begin{tabular}{|c|c|}
\hline Rights and obligations & $\begin{array}{l}\text { Management rights rights given to the village body include: } \\
\text { a. The use of environmental services provided by non-timber forest resources } \\
\text { derived from a watershed protection zone. } \\
\text { b. The same plus the use of timber, subject to IUPHHK approval, in the } \\
\text { production forest zone. } \\
\text { The obligations are: } \\
\text { a. Marking the border of the working area. } \\
\text { b. Submitting annual work plans. } \\
\text { c. Protecting the remaining forest from outside agents. } \\
\text { d. Carrying out and arranging the business of utilising forest resources. } \\
\text { e. Paying forest-use fees and contributing to the reforestation fund (in case of } \\
\text { logging) in line with the rule of law. }\end{array}$ \\
\hline Work plan & $\begin{array}{l}\text { At least once in a year the owner of the right reports the progress of the activities in } \\
\text { the village forest, which includes: } \\
\text { a. Work plan and the realisation of periodic activities: } \\
\text { - } \quad \text { Marking the border of working area } \\
\text { - Cultivating } \\
\text { - Obtaining benefits } \\
\text { b. Obstacles to implementation: } \\
\text { - Technically } \\
\text { - Administratively } \\
\text { c. Future planning }\end{array}$ \\
\hline Guidance and control & $\begin{array}{l}\text { Guidance and control of village forest management is carried out by the Minister of } \\
\text { Forestry, governor, head of regency (or mayor in case of urban areas) } \\
\text { Support provided for village forests from the central government through } \\
\text { provincial forest agencies includes: } \\
\text { a. Education and training in managing forest. } \\
\text { b. Developing the local management entity. } \\
\text { c. Guidance in arranging work plan of village forest. } \\
\text { d. Technical guidance in managing forest. } \\
\text { e. Information on market and access to capital. } \\
\text { f. Developing of business capacity. }\end{array}$ \\
\hline Termination of rights & $\begin{array}{l}\text { Rights can be terminated based on results of a joint evaluation by the forest } \\
\text { authorities and the village forest management body. Rights are terminated if: } \\
\text { a. The 35-year period expires. } \\
\text { b. Failure to meet the agreed objectives justifies sanctions. } \\
\text { c. The holder of the rights decides to withdraw. }\end{array}$ \\
\hline
\end{tabular}


The application for a Hutan Desa permit for Lubuk Beringin was supported by KKI-WARSI (an NGO), which was involved in the ICDP project in 1992, and researchers from the World Agroforestry Centre (ICRAF) who had been studying biodiversity in the area since 1998. Through projects such as RUPES the researchers had also been examining rubber agroforest management and intensification. The application also gained the attention and support of the government in Bungo district through a multistakeholder forum known as the Forest Governance Learning Group. The members of this forum, including individuals working at various agencies but not formally representing them, were instrumental in formulating the development vision for Bungo district free from factional interests, politics or institutional agendas.

\section{C2. Obtaining hutan desa recognition for Lubuk Beringin}

Lubuk Beringan's Hutan Desa application process started on 20 November, 2008 when the Directorate General of Land Rehabilitation and Social Forestry (RLPS) in the forest department clarified Regulation No. P. 49/Menhut-II/2008 on village forest during a meeting with village representatives at the planning office (Bappeda) in Bungo. Following the clarification, the village representatives officially proposed their intention to manage all the watershed protection forest (known as the Bukit Panjang-Rantau Bayur forest) within the administrative bounds of their village.

KKI-WARSI helped in completing administrative requirements, such as maps and an inventory of the natural resources within the village administrative boundaries. The proposal was completed within four months. The formal application letter from the village to the head of the district refers to support provided by KKI-WARSI and the World Agroforestry Centre (ICRAF) in the proposal development.

In early January 2009, a verification team from the forestry department visited Lubuk Beringin for a feasibility study. Finally, during a ceremony attended by 2000 people on 30 March, 2009, the Minister of Forestry officially awarded the Hutan Desa management rights to Lubuk Beringin. The village became the first in Indonesia to obtain such rights. The head of Bungo district received the decree from the Minister on behalf of the village. The forestry and plantation office was given the responsibility to guide the village in implementing their Hutan Desa work plan. The village community is, among other things, responsible for reporting illegal logging activities in the area to relevant authorities.

The process of initiating, supporting and acquiring the Hutan Desa permit is a form of action research (Bargal 2006) in the sense that researchers were actively involved together with the village and used opportunities as they arose throughout the process. Researcher-supported local action typically proceeds step-by-step with phases of reflection alternating with phases of action and 'learning loops' (Table 2). 


\section{Discussion: Understanding trust, threat and incentives}

\section{Community coherence and connectedness}

Are there specific factors in the condition or history of Lubuk Beringin that pre-disposed the village to be the pioneer of a new deal between forest authorities and village communities in Indonesia?

Table 2: Planning, action and reflection phases of the external facilitation of the village forest application, using participatory action research concepts.

\begin{tabular}{|c|c|c|}
\hline 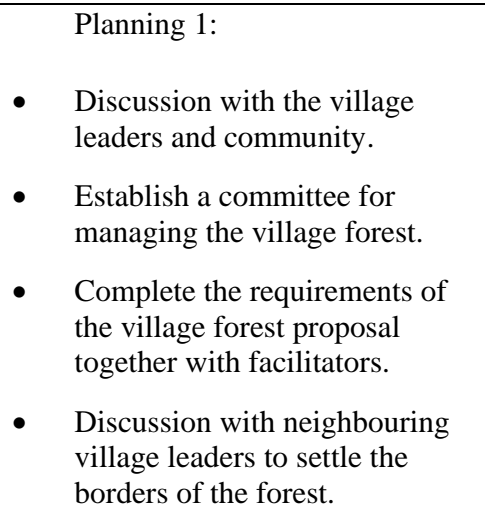 & $\begin{array}{l}\text { Action 1: } \\
\text { - } \quad \text { A committee was founded } \\
\text { with the name “Ndendang } \\
\text { Buluh Sako Batang Buat". M } \\
\text { Mukhlis became its leader. } \\
\text { - } \quad \text { Proposal letters to delineate } \\
\text { and manage village forest } \\
\text { were sent to the head of } \\
\text { Bungo district, assisted by } \\
\text { KKI-WARSI. }\end{array}$ & $\begin{array}{l}\text { Reflection 1: } \\
\text { The head of district agreed to } \\
\text { the proposal from Lubuk } \\
\text { Beringin village and ordered } \\
\text { the Forest and Plantation Office } \\
\text { to check the data in accordance } \\
\text { with the proposal. The village } \\
\text { actively helped the staff of the } \\
\text { office to complete the } \\
\text { requirements. } \\
\text { The neighbouring village } \\
\text { helped mark the village borders. }\end{array}$ \\
\hline $\begin{array}{l}\text { Planning 2: } \\
\text { Preparation of village forest } \\
\text { work plan by the committee. }\end{array}$ & $\begin{array}{l}\text { Action 2: } \\
\text { A verification team from the } \\
\text { Forestry Department visited } \\
\text { the village. } \\
\text { - The working area for the } \\
\text { village forest was confirmed } \\
\text { and the village forest } \\
\text { committee began to prove its } \\
\text { credentials. }\end{array}$ & $\begin{array}{l}\text { Reflection 2: } \\
\text { - The head of Bungo district } \\
\text { received the right for village } \\
\text { forest from the Forest Ministry } \\
\text { (MS Kaban). } \\
\text { The head of Bungo district } \\
\text { gave the responsibility to the } \\
\text { Village Forest Management } \\
\text { Committee to maintain and } \\
\text { use the village forest. }\end{array}$ \\
\hline $\begin{array}{l}\text { Planning 3: } \\
\text { - } \quad \text { Cultivation of orchid, honey } \\
\text { bee and other non-timber } \\
\text { products. } \\
\text { - Increase rubber cultivation in } \\
\text { the village forest to reduce the } \\
\text { dependency of the village on } \\
\text { the forest. } \\
\text { Plant (indigenuous) trees to } \\
\text { enhance the biodiversity of the } \\
\text { forest. } \\
\text { Propose a village development } \\
\text { program to obtain funding } \\
\text { assistance from the } \\
\text { government. } \\
\text { Make border signage helped by } \\
\text { forestry and plantation office. }\end{array}$ & $\begin{array}{l}\text { Action 3: } \\
\text { - Forestry and plantation office } \\
\text { actively and positively } \\
\text { respond to the work plan } \\
\text { - } \quad \text { Planting rubber on village } \\
\text { farms (so far } 10 \text { hectare). }\end{array}$ & $\begin{array}{l}\text { Reflection3: } \\
\text { - The village informs the } \\
\text { government of the status of the } \\
\text { forest and work plan and } \\
\text { reports the neighbouring } \\
\text { village for sanctions if it } \\
\text { harvests trees in the village } \\
\text { forest area. } \\
\text { - Shares experiences with } \\
\text { communities outside the } \\
\text { village. } \\
\text { Receives a Village for } \\
\text { Conservation award from the } \\
\text { Forestry Minister. }\end{array}$ \\
\hline
\end{tabular}

For more than a decade, Lubuk Beringin had been interacting with KKI-WARSI in the ICDPTNKS protection program. Although the ICDP as a whole may have failed, the process it 
started can be followed to Lubuk Beringin's Hutan Desa outcome. Although Suparman (1999) noted that the empowerment programs of the ICDP only reached rural elites, in the case of Lubuk Beringin the discussions ultimately involved all. This suggests that the time pressure on projects such as ICDP may not match with reality and success or failure may be judged too early.

The RUPES project on biodiversity and environmental services rewards also employed participatory, collaborative and co-learning approaches. It operated on the basic assumption that effective management of natural resources, including biodiversity conservation, occurs whenever there is synergy among human, natural and social capital (Van Noordwijk et al. 2004). Social capital in the village was developed using an interactive co-learning approach, which allowed dialogue among as many relevant stakeholders as possible to share knowledge, define problems and find solutions. The community was considered as a collaborator having an active role in designing priorities, while the outsiders had responsibility for making the process of conservation and development actually happen. Reaffirming the hypothesis of Ostrom (1990) that self-organisation defines a community, the following principles were applied: 1) the boundary was clearly defined in the Lubuk Beringin landscape taking account of historical facts, and; 2) the community affected by the rules participated in modifying the rules.

\section{Win-win-win solution?}

Analysis of the benefits that the district, provincial and central government agencies derived from the Hutan Desa agreement suggests that public discussion about conflicts as a deterrent to REDD investment in Indonesia as a whole, and in Jambi province specifically, has played a role. Although the REDD context is not reflected in the formal decisions (as it may give the impression of undue external pressure), it was expressed in informal interviews with those involved in the approval process.

For example, the watershed protection forest status does not allow extraction rents and the cost of protecting the area is a drain on district government resources. This is supposedly balanced by gains in more regular waterflow and reduced risk of landslides that disturb road infrastructure or can lead to loss of lives. The public display by the Minister of Forestry in announcing the Hutan Desa agreement just before parliamentary elections suggests that a showcase was indeed welcome after years of promises that benefits from forests should be more widely shared.

Bungo's forest governance learning group served as a venue for open discussions among activists about reforming forest governance. This forum is informal and the topics of discussion depend on the members' interests. The members of the forum do not represent their institutions, so the meetings provide a safe space for open discussion and learning.

Table 3 presents an analysis of the relevance of the REDD debate to Hutan Desa agreements. The analysis is based on discussions with various stakeholders at the national, provincial, regency and local levels. Stakeholders' approval of such stewardship agreements was synthesized by a simple score of positive, neutral or negative impacts on their group multiplied by a five-point ranking of the power to facilitate or delay the approval.

In the table, the situation with and without expectation of benefits from REDD (of reducing carbon emission from deforestation and degradation) was reconstructed. Without (or before) 
expectations of REDD benefits, the national and provincial discussions tended towards blocking the proposal because groups that expect Hutan Desa proposals to hinder the allocation of forests to the forestry industry had more influence than the social forestry groups.

The REDD debate may have tipped the balance at both central and provincial level because expectations of benefits were clearly expressed. Interestingly, in this analysis the major interest groups that were opposed to the Hutan Desa agreement could not openly express opposition because the agreement involves watershed protection forest that is out of reach of the forestry industry (even though de facto use has been possible). Similarly, at village and regency levels the groups currently benefitting from illegal logging could not openly express their position.

Given the multilevel approval process and the lack of opportunities for trade-off of different matters between levels of government (as opposed to within each level), it may be reasonable to expect that the final outcome has to be at least neutral for each level of governance before agreement can be achieved.

Table 3: Analysis of stakeholder positions and power at local, regency, provincial and national levels based on 'expert opinion' of those involved in the process. The overall score at each level is calculated with and without expectations of REDD benefits.

\begin{tabular}{|c|c|c|c|c|c|c|c|c|}
\hline \multirow[b]{3}{*}{ Level } & \multirow[b]{3}{*}{ Stakeholders } & \multirow{3}{*}{$\begin{array}{c}\text { Net } \\
\text { benefit }\end{array}$} & \multirow{3}{*}{ Power } & \multirow{3}{*}{ Open? } & \multicolumn{4}{|c|}{ Influence on decision } \\
\hline & & & & & \multirow{2}{*}{$\begin{array}{c}\text { w/ } \\
\text { REDD }\end{array}$} & \multirow{2}{*}{$\begin{array}{c}\text { w/o } \\
\text { REDD }\end{array}$} & \multicolumn{2}{|c|}{ Silencing illegal voices } \\
\hline & & & & & & & & w/o REDD \\
\hline \multirow[t]{3}{*}{ National } & $\begin{array}{l}\text { Ministry of } \\
\text { Forestry } \\
\text { pulpwood-supply } \\
\text { interests }\end{array}$ & -1 & 5 & 0 & -5 & -5 & 0 & 0 \\
\hline & $\begin{array}{l}\text { Ministry of } \\
\text { Forestry social } \\
\text { forestry interests }\end{array}$ & 1 & 2.5 & 1 & 2.5 & 2.5 & 2.5 & 2.5 \\
\hline & $\begin{array}{l}\text { Ministry of } \\
\text { Forestry REDD } \\
\text { interests }\end{array}$ & 1 & 3 & 1 & 3 & & 3 & \\
\hline \multirow[t]{3}{*}{ Province } & $\begin{array}{l}\text { Provincial } \\
\text { pulpwood supply } \\
\text { interests }\end{array}$ & -1 & 2 & 0 & -2 & -2 & 0 & 0 \\
\hline & $\begin{array}{l}\text { Provincial } \\
\text { waterflow } \\
\text { interests }\end{array}$ & 1 & 1 & 1 & 1 & 1 & 1 & 1 \\
\hline & $\begin{array}{l}\text { Provincial } \\
\text { REDD interests }\end{array}$ & 1 & 1 & 1 & 1 & & 1 & \\
\hline \multirow[t]{4}{*}{ Regency } & Regent & 1 & 5 & 1 & 0 & 0 & 0 & 0 \\
\hline & $\begin{array}{l}\text { Regency forestry } \\
\text { law enforcement } \\
\text { unit }\end{array}$ & 1 & 2 & 1 & 1 & 1 & 1 & 1 \\
\hline & $\begin{array}{l}\text { Opportunity to } \\
\text { collect revenue } \\
\text { for forest use }\end{array}$ & 2 & 2 & 4 & 4 & 4 & 4 & 4 \\
\hline & $\begin{array}{l}\text { National park } \\
\text { authority }\end{array}$ & 1 & 2 & 1 & 2 & 2 & 2 & 2 \\
\hline
\end{tabular}




\begin{tabular}{|c|c|c|c|c|c|c|c|c|}
\hline \multirow[t]{5}{*}{ Village } & $\begin{array}{l}\text { Village } \\
\text { leadership }\end{array}$ & 2 & 2 & 1 & 3 & 3 & 3 & 3 \\
\hline & $\begin{array}{l}\text { Well-off farmers } \\
\text { (foregoing rubber } \\
\text { intensification) }\end{array}$ & 0 & 2 & 1 & 0 & 0 & 0 & 0 \\
\hline & $\begin{array}{l}\text { Local operators } \\
\text { of illegal logging }\end{array}$ & -2 & 1 & 0 & -2 & -2 & 0 & 0 \\
\hline & $\begin{array}{l}\text { Women and } \\
\text { children }\end{array}$ & 1 & 1 & 1 & 1 & 1 & 1 & 1 \\
\hline & $\begin{array}{l}\text { Local } \\
\text { hydropower } \\
\text { operators and } \\
\text { participating } \\
\text { households }\end{array}$ & 1 & 1 & 1 & 0.5 & 0.5 & 0.5 & 0.5 \\
\hline \multirow[t]{2}{*}{ External } & Provincial NGO & 1 & 2 & 1 & 4 & 4 & 4 & 4 \\
\hline & $\begin{array}{l}\text { International } \\
\text { research centre }\end{array}$ & 2 & 1 & 1 & 2 & 2 & 2 & 2 \\
\hline \multirow[t]{4}{*}{ Totals } & & & \multicolumn{2}{|c|}{$\begin{array}{l}\text { Sum at national } \\
\text { level }\end{array}$} & 0.5 & -2.5 & 5.5 & 2.5 \\
\hline & & & \multicolumn{2}{|c|}{$\begin{array}{l}\text { Sum at } \\
\text { provincial level }\end{array}$} & 0 & -1 & 2 & 1 \\
\hline & & & \multicolumn{2}{|c|}{$\begin{array}{l}\text { Sum at regency } \\
\text { level }\end{array}$} & 5 & 5 & 5 & 5 \\
\hline & & & \multicolumn{2}{|c|}{$\begin{array}{l}\text { Sum at village } \\
\text { level }\end{array}$} & 2.5 & 2.5 & 4.5 & 4.5 \\
\hline
\end{tabular}

\section{Role of external agents}

External agents had interacted with the local community for over a decade. A detailed analysis of how components of this interaction influenced the quality of self-organised forest governance is beyond the scope of this paper. In Bungo district, as mentioned by local government staff, the close interaction of the local community with NGOs as facilitators has been very important (Adnan et al. 2008). Community development programs of the NGOs provided technical expertise, facilitated information exchange with other rural communities and created a forum for conflict resolution. However, local action also requires legal back-up in dealing with outside agents (for example, those involved in illegal logging) and to achieve reciprocity with the municipal government. The active roles of the World Agroforestry Centre (ICRAF) and KKI-WARSI in the district-level forest learning group and of KKI-WARSI at provincial level helped to build trust with the village community and helped forest officials understand that rubber agroforests combine environmental and productivity functions that are compatible with the watershed protection forest status (Joshi et al. 2003).

\section{E. Relevance for the international REDD debate}

The designation as village forest of 84 percent of Lubuk Beringin's territory can be a step toward such schemes for neighbouring villages or the whole Rantaupandan valley and/or zone surrounding the national park.

The factors that helped make Lubuk Beringin a special case that could serve as a pioneer for Hutan Desa agreements, along with the scrutiny needed of those in forestry institutions who 
mistrust any local community, make it less likely that the result can be easily extended to other villages.

There are continuing efforts to test the hypothesis that transaction costs can be reduced once there are a few successes. Replication processes have started in Bukit Panjang, Bukit Pohong in Sungai Telang, Bukit Singirik and Bukit Rantau Bayur in Senamat Ulu village. These contiguous areas are all within the protected forest area of Bukit Panjang-Rantau Bayur, covering 13529 hectares. There has been previous recognition of small parts (not exceeding 1000 hectares) of the forest in Bungo district as “customary forest” (Endah 2008, Hadi et al. 2008). The existing agreements for these small areas are better than what was achieved before, but do not achieve their maximum potential reach and relevance. The replication of the Hutan Desa scheme in these areas could be a model of collective management of forest areas involving various villages under a clear government regulation.

For the villagers of Lubuk Beringin, the increased tenure security is a highly valued reward and they are aware that this is subject to performance in forest protection. In as far as the approval of forest authorities has been linked to expectations of receiving REDD funding, the benefits for local communities can, for a change, have preceded benefits at government level.

Much of current REDD debate is about benefit sharing and focussed on financial flows. The key to the success of Lubuk Beringin is that multiple currencies are involved: the primary benefit to the community is security of rights and opportunities to derive income from their agroforests; and the primary benefit for government agencies is that they can meet preconditions for REDD investment, all at low financial cost.

Programs on forest carbon in Bungo district are now being established based on regulation No. P.68/Menhut-II/2008 of the Forestry Minister about allocating REDD funds and No. P.30/Menhut-II/2009 about REDD in the framework of the climate change convention. In order to be part of national and international REDD fund allocations, institutions are required that have a clear mechanism for forest protection and distribution of benefits and that are able to monitor the performance of a REDD funding program in Indonesia. The Hutan Desa designation of Lubuk Beringin may well become one of the starting points for such a process. It may also prove to be a key component of the self-funded NAMA commitment by Indonesia to the global community to stabilise national emissions at the 2005 level and to seek a shift to emissions that make more tangible contributions to the national economy. 


\section{Conclusions}

The case of the Hutan Desa designation of Lubuk Beringin has been shown to be a way to reduce transaction costs for the initial phases of REDD mechanisms.

Where public policies have inconsistencies and have not reconciled conflicting interests in future forest-use options, imposing a REDD scheme as part of an international regime may face high transaction costs and be unattractive to international investors. In a co-investment paradigm (as discussed in van Noordwijk and Leimona 2010), the options of negotiated tenure conditional on environmental service maintenance on land that ultimately remains under state control are an important category of rewards for environmental services, as well as a precondition for the use of other paradigms in Payment for Environmental Services schemes. The current level of control by forest authorities through development, approval and implementation of management plans to enhance environmental services may appear excessive for the area especially in comparison to the lack of accountability by the state authorities in areas where they have been in charge. But local sovereignty in managing the environment for local-plus-external benefits has to be earned in a step-by-step fashion.

Success of this conditional tenure paradigm in the international REDD context will require further trust-building and reciprocity in redressing the current inequalities and conflicts over Indonesia's forest resources. As a means of conflict resolution, the Hutan Desa case in Lubuk Beringin features the importance of both bonding (or horizontal) and bridging (or vertical) forms of social capital between actors while addressing the rights issues of the local people. Reference to local wisdom and traditions in managing mixed woody vegetation that combines planted trees (in this case, rubber) and local plant species that replicates the natural forest process and patterns in the protective agroforests, form a big step forward in developing fair and efficient REDD schemes. 


\section{References}

Adnan H, Tadjudin D, Yuliani EL, Komarudin H, Lopulalan D, Siagian YL, Munggoro DW. eds. 2008. Belajar dari Bungo: mengelola Sumberdaya alam di era desentralisasi. Bogor, Indonesia: Center for International Forestry Research.

Angelsen A, Brown S, Loisel C, Peskett L, Streck CA, Zarin, D. 2009. Reducing emissions from deforestation and forest degradation (REDD): An options assessment report. Washington, DC: The Meridian Institute.

Bargal D. 2006. Personal and intellectual influences leading to Lewin's paradigm of action research. Action Research 4: 367-388.

Djogo T, Syaf R. 2003. Decentralization without accountability: power and authority over local forest governance in Indonesia. In Suryanata K, Fox J, Brennan S, eds. Issues of decentralization and federation in forest governance. Proceedings from the Tenth Workshop on Community-Based Management of Forestlands, 30 June 3-25 July 2003. Honolulu, Hawaii: p. 9-26. (Available from http://www.eastwestcenter.org/fileadmin/stored/pdfs//FoxIssuesofDecentralization.pdf \#page=12)

Endah RDDR. 2008. Hutan adat Batu Kerbau: sisa-sisa kearfian lokal. In Adnan H, Tadjudin D, Yuliani EL, Komarudin H, Lopulalan D, Siagian YL, Munggoro DW, eds. Belajar dari Bungo: mengelola Sumberdaya alam di era desentralisasi. Bogor, Indonesia: Center for International Forestry Research: p. 65-82.

Fay C, Michon G. 2005. Redressing forestry hegemony: when a forestry regulatory framework is replaced by an agrarian one. Forest, Trees and Livelihoods 15 (2): 193209.

Galudra G, Sirait M. 2009. A discourse on Dutch colonial forest policy and science in Indonesia at the beginning of the 20th century. International Forestry Review 11: 524533.

German LA, Keeler A. 2010. "Hybrid institutions”: applications of common property theory beyond discrete property regimes. International Journal of the Commons 4: 571-596.

Gomez-Baggethun E, De Groot R, Lomas PL, Montes C. 2010. The history of ecosystem services in economic theory and practice: from early notions to markets and payment schemes. Ecological Economics 69: 1209-1218.

Hadi M, Komarudin H, Schagen M. 2008. Bebijakan kehutanan, aksi kolektif dan hak properti: sebuahy pelajaran dari Bungo. In Adnan H, Tadjudin D, Yuliani EL, Komarudin H, Lopulalan D, Siagian YL, Munggoro DW, eds. Belajar dari Bungo: mengelola Sumberdaya alam di era desentralisasi. Bogor, Indonesia: Center for International Forestry Research. p. 365-387.

Helmi, Yonariza. 2002. Project socio-economic impact study of integrated conservation and development project (ICDP) Kerinci Seblat National Park (KSNP). Padang, Indonesia: 
Center for Irrigation, Land and Water Resource and Development Studies, Andalas University. (Available from http://www.unand.ac.id/psi-

sdalp/download/research/tnks.pdf)

[IFCA] Indonesia Forest Climate Alliance. 2007. Reducing emissions from deforestation and forest degradation in Indonesia: REDD methodology and strategies: summary for policy makers. Jakarta: Indonesia Forest Climate Alliance. (Available from http://www.dephut.go.id/INFORMASI/LITBANG/IFCA/Summary\%204\%20policy\%2 0makers_final.pdf)

Joshi L, Wibawa G, Beukema HJ, Williams SE, Van Noordwijk M. 2003. Technological change and biodiversity in the rubber agroecosystem. In Vandermeer JH, ed. Tropical agroecosystems: new directions for research. Boca Raton, Florida: CRC Press. p.133157.

Kuncoro SA, Van Noordwijk M, Martini E, Saipothong P, Areskoug V, Ekadinata A, O'Connor T. 2006. Rapid agrobiodiversity appraisal (RABA) in the context of environmental service rewards: protocols for data collection and case studies in rubber agroforest in Bungo district, Jambi, Indonesia and fragmented forest in north Thailand. Bogor, Indonesia: World Agroforestry Centre (ICRAF).

Kusters K, De Foresta H, Ekadinata A, Van Noordwijk M. 2007. Towards solutions for state vs. local community conflicts over forestland: the impact of formal recognition of user rights in Krui, Sumatra, Indonesia. Human Ecology 35: 427-438.

Ostrom E. 1990. Governing the commons. New York: Cambridge University Press.

Pfundt JL, Koponen P, O’Connor T, Boffa JM, Van Noordwijk M, Sorg JP. 2008.

Biodiversity conservation and sustainable livelihoods in tropical forest landscapes. In Lafortezza R, Chen J, Sanesi G, Crow TR, eds. Patterns and processes in forest landscapes: multiple use and sustainable management. Berlin: Springer.

Stern N. 2008. The cconomics of climate change. American Economic Review 98: 1-37.

Suparman. 1999. Proses pendampingan pada masyarakat tepian hutan. Thesis for Magister of Social Science. Jakarta: University of Indonesia.

Suyanto S, Permana RK, Khususiyah N, Joshi L. 2005. Land tenure, agroforestry adoption and reduction of fire hazard in a forest zone: a case study from Lampung, Sumatra, Indonesia. Agroforestry System 65: 1-11.

Suyanto S, Muharrom E, Van Noordwijk M. 2009. Fair and efficient? How stakeholders view investments to avoid deforestation in Indonesia. Policy Brief 8. Bogor, Indonesia: World Agroforestry Centre (ICRAF).

Van Noordwijk M, Leimona B. 2010. CES/COS/CIS paradigms for compensation and rewards to enhance environmental services. World Agroforestry Centre (ICRAF) Working Paper 100. Bogor, Indonesia: World Agroforestry Centre (ICRAF).

Van Noordwijk M, Purnomo H, Peskett L, Setiono B. 2008. Reducing emissions from deforestation and forest degradation (REDD) in Indonesia: options and challenges for 
fair and efficient payment distribution mechanisms. World Agroforestry Centre (ICRAF) Working Paper 81. Bogor, Indonesia: World Agroforestry Centre (ICRAF).

Van Noordwijk M, Chandler F, Tomich TP. 2004. An introduction to the conceptual basis of RUPES: rewarding upland poor for the environmental services they provide. Bogor, Indonesia: World Agroforestry Centre (ICRAF).

Verchot LV, Petkova E. 2009. The state of REDD negotiations: consensus points, options for moving forward and research needs to support the process. A background document for the UN-REDD sponsored support to regional groups. Bogor, Indonesia: Center for International Forestry Research.

Williams SE, Van Noordwijk M, Penot E, Healey JR, Sinclair FL, Wibawa G. 2001. On-farm evaluation of the establishment of clonal rubber in multistrata agroforests in Jambi, Indonesia. Agroforestry Systems 53: 227-237. 


\section{Attachment 1}

\section{BEITIA ACARA \\ KESEPAKATAN BATAS WILAYAH DUSUN LUBUK BERINGIN KECAMATAN BATHIN UI ULU KABUPATEN BUNGO}

Pada hari Jumat, tanggal 6 Maret 2009 bertempat di Dusun Lubuk Beringin, kami yang terdiri dari Rio Dusun Lubuk Beringin, Rio Dusun Senamat Ulu, Rio Dusun Laman Panjang dan Rio Dusun Buat Kecamatan Bathin III Ulu Kabupaten Bungo telah melakukan musyawarah tentang kesepakatan batas wilayah dusun Lubuk Beringin. Berdasarkan hal diatas disepakati batmwa.

Pertama - Wlayah Dusun Lubuk Beringin berbatasan dengan Dusun Buat disebelah Barat dan Utara dengan batas golek air guling batu di Bukit Panjang. disebelah Timur dan Utara berbatasan dengan Dusun Laman Panjang berdasarkan golek air guling batu di Bukit Gedang Sebelah Selatan dengan Kecamatan Pelepat.

Kodua : Batas wilayah tersebut dengan sebenamya merupakan batas wilayah dusun Lubuk Beringin, termasuk didalamnya kawasan yang diusulkan untuk menjadi hak pengelolaan Hutan Desa Dusun Lubuk Beringin seluas 2356 Hektar yang berada didalam kawasan Hutan Lindung Bukit panjang Rantau Bayur

Ketiga : Dengan adanya kesepakatan antar para Rio yang wilayahnya berbatasar langsung dengan dusun Lubuk Beringin, diharapkan dapat mempercepan proses upays penetapan Areal Kerja Hutan Desa Dusun Lubuk Beringin dengan SK Menteri Kehutanan

Keempat : Berita Acara ini dibuat sebagai bahan untuk memperjelas dan memastikan wilayah pengelolaan Hutan Desa Dusun Lubuk Beringin, untuk menghindan terjadinya konflik batas wilayah dan gugatan, wilayah dikemudian hari.

Demikianlah Berita Acara ini dibuat atas kesepakatan bersama.

Dietapkan di Dusun Lubuk Beringin

Pada tanggal, 6 Maret 2009

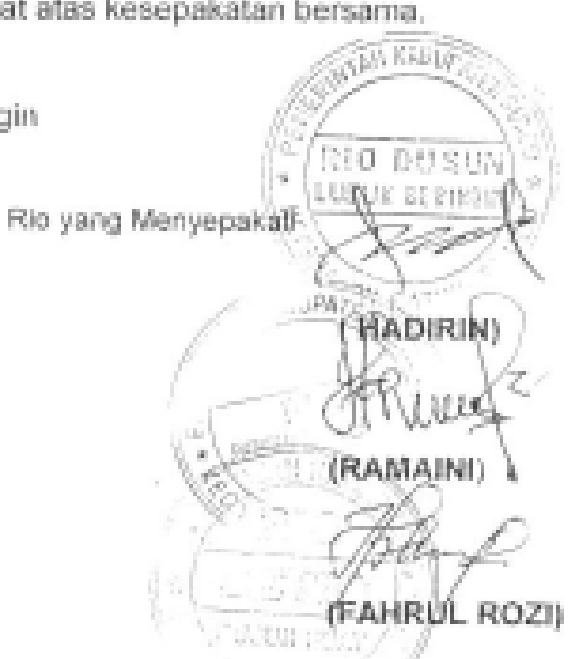

Rio Dusun Buat

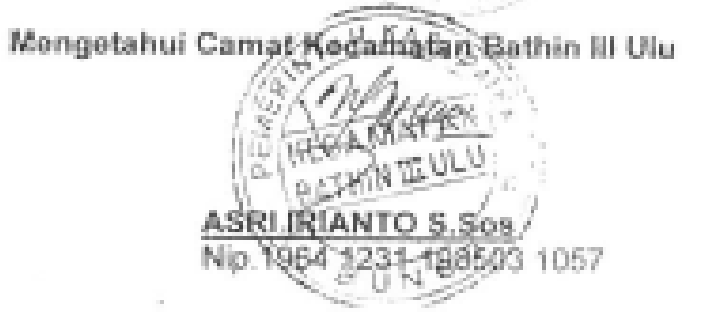




\title{
Attachment 2
}

\author{
BERITA ACARA HASIL VERIFIKASI \\ PENETAPAN HUTAN DESA \\ DI DUSUN LUBUK BERINGIN KECAMATAN BATHIN III ULU \\ KABUPATEN BUNGO PROVINSI JAMBI \\ NOMOR: BA /BPS-3/2009 \\ TANGGAL MARET 2009
}

Pelaksanaan Verifikasi Penetapan Areal Kerja Hutan Desa didasarkan atas usulan Bupati Bungo dengan surat No 522/2312/Hutbun tanggal 17 Desember 2008 perihal Usulan Penetapan Areal Kerja Hutan Desa, dilakukan sebagai tindak lanjut ketentuan pasal 7 Peraturan Menteri Kehutanan Nomor P.49/Menhut-II/2008 tentang Hutan Desa.

Acuan pelaksanaan verifikasi adalah keputusan Menteri Kehutanan Nomor SK.76/Menhut-II/2009 tanggal 4 Maret 2009 tentang Tentang Tim Verifikasi Hutan Desa, dan Peraturan Direktur Jenderal Rehabilitasi Lahan dan Perhutanan Sosial Nomor P.Q3/V-Set/2008 tanggal 3 Maret 2009 tentang Pedoman Verifikasi Hutan Hutan Desa.

Pada hari ini Sabtu tanggal Tujuh Bulan Maret Tahun Dua Ribu Sembilan, kami yang bertandatangan di bawah ini Tim Verifikasi Hutan Desa di Dusun Lubuk Beringin Kecamatan Bathin III Ulu, Kabupaten Bungo, Provinsi Jambi, dengan hasil Verifikasi sebagai berikut :

\section{GAMBARAN UMUM}

Kawasan Hutan Desa yang diusulkan oleh masyarakat Dusun Lubuk Benngin merupakan kawasan Hutan Lindung Rantau Bayur Bukit Panjang Kelompok Hutan Merangin Alai yang berada di wilayah administrasi dusun seluas \pm 2.356 hektar yang merupakan hulu DAS Batang Bungo sebagai penyangga kehidupan masyarakat, baik sebagai fungsi hidroorologi seperti sumber air, minum, irigasi sawah, lubuk larangan/perikanan darat, MCK, sarana transportasi/pengangkut hasil karet rakyat, sumber energi bagi kineir air penghasil listrik desa/mikrohidro, maupun sebagai penyangga kawasan konservasi Taman Nasional Kerindi Seblat (TNKS), koridor loncatan jenis hewan tertentu serta persediaan karbon yang berkorelasi kuat dengan tumbuhan yang ada di dalamnya. 
Dari hasil kajan inventori partisipatif di dalan kawasan Hutan Lindung Rantay Bayu Bukt Panjary terdapat 971 species pohoi, 37 spoich mamala, Kawasan ini sebegian besar didominasi oleh topograf bertukt dengan ketinggian antora 900-1316 meter di atas permukan but

Masranake scjok tahur 1997 telah menjaga kawasan hutan in dengan berpegang pada Kesepokatan Konservasi Desa (KKD), yang menupakan proses panjang yang dibangun oleh mayarakat untuk menjaga keberlanjutan fungsi ekosistem kawasan hutan di vilayah dusun.

Ada beberapa kesepakatan penting antara lain bahwa masyarakat tidak akan menpambil hasil hutan kay dan non kayu serta tidak membuka bah pertanian dalam kawasan hutan lindurig dan kawasan ThSS, pengambilan hasil huian kayu dan non kays serta perbukaan lahan pertanän poda Kawasan Hutan Dea di luar kamasan Hutwn Lindung dan THKS harus gejin Des (setelah disetujui Pemdes, BFD, Takoh Adat dan Tokoh Apama), tidak akan mengolah lahan pertanian secara terus menerus pada bahan mininglouram, pingpr sungai, huliu sungai supara didak terjadi longsor, banjyerosi atau sumber pengairan sawah tidal, turganggu.

\section{PROSES VERIFIKASI}

A. Pengumpulan data dan informasi

Pengumpulan data dan infomasi tenteng adninistras rang domiliki olch Dusun Lubuk Beringin Mrta data pendukung lainnya dengan cara mengumpulkan dan mewawancarai pejabat terkait, tokoh mssarakat toksh adat.

B. Koordinasi dengan Dras Kehutanan Provins Janbi.

Melakukari rapatpetomuan dengan Dinas Proping besetu jujaranya yang terkait untuk mengoali keterangan-keterangan setagai pendukung proses verifikas

C. Diskusi dengan Bupati dan Kepala Dinas Kethutenan Kabupaten Bungo. Untuk mengklarifikasi usulan Bupati tentang data-data lungsi kwasan, peti, luasan dan kondis topografi dan kondsi masyarakat vang akan dipakai sebagai masukan dalam melaksaniken verifkasi. 
D. Diskusi atau wawancara dengan Ro/Kepala Cusun dan Warga Dusun. Melakukan pertemuan dengan Kepala Dusun beserta selurul aparatuya dan masparakat untuk menggali keseriusan masyarakat dusun atas usulan Hutan Desa serta mengklarifkasi data-data yang berkaltan dengan Hutan Desa dan Purnbentukan Lembaga Desa apakah sudah 5euai dengan P. 49 Menhut-ii/2008 tentang Hutan Des.

E. Observasi Lapangan.

Dilakukan deth Tim Teknis Tepadu antara Dițen RuPs, Ditjen Planologi Ketivtalan dan aparat Pemerintah Doerah (Prownsi, Kabupaten) dan masyarakat Lubuk Beringin dengan tujuan untuk memastikan batasbatas wilayah Hutan Desa dan wilayah administras serta topografi, potensi dan penutupan lahan.

\section{III.BATASAN ANALISIS}

A. Tin verifiks hanya bertugas sebatas memmenifiksi alas usulan penetapan areal keja Hutan Dusa dari Bupati dengan surat No. 522/2312/Hutbun tanggal 17 Desember 2008.

B. Tim tidak memverifkasi dan tidak bertangong jawab terhadap proses atou kegiatan yang ad sebelumnya di kawasan Hutsn Lindung Bukn Panjang Rantau Bapur kelompok hutan Merangin Alai Kabupaten Bungo Provinsi Jambi.

\section{DESKRIPSI VERIFIKASI}

\section{A.Kepastan Kawasan}

1. Status Kawasan.

Seara hukurn status kawasan terdir dari Hutan Hak dan Hutan Negara, sedangkan status kawasan hutan rang diajukan deh Desa Lubuk Beringin barstatus kowasan Hutan Negara.

2. Fungsi Kawasan.

Fungsi kawasan terdiri dari fungsi konkervasl, fungsi lindung dan fungsi produksi. 
Hutan Des yang dajwkan odeh Desa Lubuk Beringin merupakan fungsi lindung.

3. Hakj/Perijinan.

Setelah dikdarifikas di lapangen pada hawasan Hutan Dese pang diajukan bebas dari hak atau jin yang dibenkan kepada phak ketiga, namun ditemukan sebsgian kecil tegakan karet rahot yang dimanfadkan menurut, prinsip-prinsip kescpakatan konservas deso.

4. Batas-batas kamasan hutan yang diusulkan.

- Sebelah timur bertatas dengan Hutan Lindung Bukit Panjang Rantau Bayr.

- Sebelah Barat betbatas dengan Hutan Lindung Bukt Panjang Rantau Bayur

- Sebelah Utara betbatas dengan Kebun Masarakat Libuk Beringin

- Sebelah Selatan berbutas dengar Hutan Lindung Bukit Panjang Rantau Bayur:

B. Butas Administrasi Desa.

- Sebelah Burat dan Utara berbatas Dusun buat dengen batas polek air guling batu di Bukit Panjang

- Sebelah Timur der Utara berbatas Dusun Laman Panjang dengan batas golek air guling betu di Bukit Gedang

- Sebelah Selatan berbatas Kecamatan Pelepat.

Batas administrasi desa tersebut dkepakati bersang dan dituangkan dalam Berita Acara Kesepakatan yang ditandatanyani deh Kepala Dusur Lubuk Beringin, Kepala Dusun Laman Panjang, dan Kopala Dusun Buat serta diketahui oleh Camat Buthin inI Ulu.

C. Permohonan Kepala Dusun.

Kepala Dusun Lubuk Beringin sudah mengajukan surat pemolonan penetapan Areal Kerja Hutan Desa kepoda Bupoti Nomar 32/D\&/.b/V/2008 tanggal 5 November 2008 peithal Remohonan Penetupan Areal Kej̦a Hutan Desa

D. Kepedulian Pemerintah Dusun tehadap Kelestarian Hulan.

Pemerintah Dusun Lubuk Eeringin sangat peduli tertadap kelestarian hutan, hal ini dapat digambarkan adanya Kesepakatan Koservasi Desa (KKD) Yang berbunyi antara tain masyarakat sepakat untuk tidak. mengolsh lahan-lahsn pattanian secara tenus menenus (Behumo) poda lahan-bhan miringlouram, pinggir sungai, dan hulu-hulu sungai agar tidak teradi longsor, banjir, erosi ateu sumber pengaran swah tidak 
terganggu, tidak mengambil hasil hutan kayu pada kowasan hutan lindung.Mengambil hasil hutan kayu pala lahan milk harya untuk kepentingan sendiri dan tidak boleh diperjualbelikan.

E. Kondis Penutupan Lahan.

Kondisi pesutupan lahan berupa hulan primer dengan jens pohot utama kelompok meranti (shorcu sp), tembesu, kulim, medang, kolat, kempas, keranjl, keruing, dll. Menunut penelitian secara participatif; bahwa secare umum terdapat 971 spesies pohon dan 37 speses mamalia antara lain sepertil samang, simpai, benang madu, babi hutan, trenggiling beruk, monyet, biswik, ular, tapir, musug dil. Sodangkan jenis aves antara lain seperti e lang, mural, kutbang, oxys, terkukuk, ayam hutan.

F. Kondisi Topognafi.

Kawason ini didominasi olth topgrafi berbukit sampa dengan curam dengan ketinggian Intara 900 sampai denpan 1316 meter di atas permukaun laut (dp).

\section{v. HASIL ANALISIS.}

- Fungsi kawasan telah sesuai ketentuan dalan Pemenhut P.49Mrrinut11/2008, vaitu berada dalam Kowasan Hutan Lindung.

- Status dan Hak telah sesuai dengun peraturan peruadang-undangan, yaitu dalam kawasan hutan negara.

- Masarakat poduli, antusias dan siap mengelala serta menjaga hutan dese:

- Telah dimulai insiasi pembentukan kenbuga dasa.

- Telah ada kesepakatan batas-batas Hutan Desa, baik batas adminisuatuf maupun batas kawaban, dengan dusun-dusur tetanga.

- Apsrat Pemerintah Docrah Kabupoten Bungo dan Proving Jambi memben dukungan penuh terhadap keinginan masyarakat Dusun Lubuk Beringin untak mendapatkari penctopan areal kerja hubn deca.

- Prosedur pengusulan sudah dilakukan scsua dengan Pomenhut P.49/menthut-IL/2008. 


\section{REKOMENDASI.}

- Berdasarkan fokta-fakta yang ditemukan olech Tim Tekris di lapangan dan berbagai informasi dan data serta hasil wawancare dan coservasi dengan pihak terkait, maka Tim Verifkasi merekomendasikan kepada Menteri Kehutanan untuk menetapkan sebagai Areal Kerja Hutan Desa Lubuk Beringin.

- Masyarakat Dusun Lubuk Beringin yang tolah mendapat Areal Kerja Hutan Desa agar:

a. Dapat menjaga kelestarian status dan fungsi Hutan Desa.

b. Mengembangkan model-model pemanfastan hutan lindung sepert pemanfaatan kawasan, jasa lingkungan dan pemungutan hasil hutan bukan karu.

Demikian Berita Acara int Jlbuat, sebagai bahan pertimbangan dalam Penetapan Areal Kerja Hutan Desa.

Mengetahui :

Kepala Einas Kehutanan dan
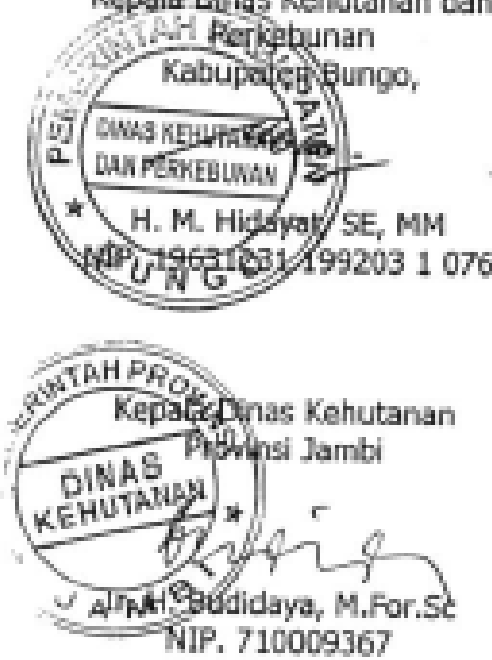

Tim Verifikasi :

1. Ir. Robert CD Kaban, MM (Ditjen RLPS)

2. Dra. Indrawati, MM (Ditjen RLPS)

3. Zulfikar $\mathrm{Ali}, \mathrm{SH}_{q} \mathrm{MSi}$ (Ditjen RLPS)

4. Anwar Sofyen, S.Hut. (Citjen Planologi Kehutanan)

5. Ir. Ahriman Ahmad (BPDas Batanghari Jarúi)

6. Sulardi, SP (Dishut Provinsi Jambi)

7. Iman Budisetiawan, S.Hut. (Dishutbun Kab. Bungo)
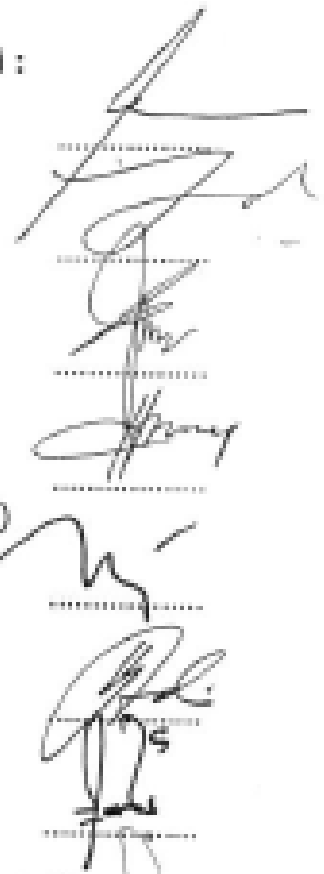

8. Suwardi (Ditjen fiLPS)

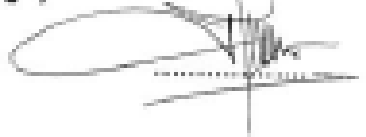




\title{
Attachment 3
}

\author{
PEMERINTAH KABUPATEN BUNGO \\ KECAMATAN BATIN III ULU \\ DUSUN LUBUK BERINGIN
}

\section{PERATURAN DUSUN LUBUK BERINGIN}

KECAMATAN BATIN III ULU KABUPATEN BUNGO

NOMOR 01 TAHIUN 2009

TENTANG

KELOMPOK NDENDANG HULU SAKO - BATANG BUAT

DENGAN RAHMAT TUHAN YANG MAHA ESA

\author{
KEPALA DUSUN LUBUK BERINGIN
}

Menimbang : a. Bahwa dalam rangka menetapkarı rencana Lembaga Desa yang mengelola hutan desa, maka perlu menetapkan Keiompok Ndendang Hulu Sako - Batang Buat

b. bahwa berdasarkan pertimbangan sebagaimana dimaksud pada huruf a, perlu membentuk Peraturan Dusun tentang Kelompok Ndendang Hulu Sako - Batang Buat

Mengingat : 1. Undang-undang Nomor 7 Tahun 1965 lentang Pembentukan Daerah Tingkat II Sarolangun Bangko dan Daerah Tingkat II Tanjung Jabung dengan mengubah Undang-Undang Nomor 12 Tahun 1956 tentang Pembentukan Daerah Otonom Kabupaten di Propinsi Sumatera Tengah (Lembaran Negara Republik Indonesis Tahun 1965 Nomor 60, Tambahan Lembaran Negara Republik Indonesia Nomor 2755);

2. Undang-Undang Nomor 5 Tahun 1980 tentang Konservasi Sumberdaya Alam Hayati dan Ekosisternnya (Lembaran Negara Tahun 1990 Nomor 49, Tambahan Lembaran Negara Nomor 3419);

3. Undang-Undang Nomor 23 Tahun 1997 tentang KetentuanKetentuan Pokck Pengeiolaan Lingkungan Hidup (Lembaran Negara Tahun 1997 Nomor 68, Tambahan Lembaran Negara Nomor 3699);

4. Undang-Undang Nomor 41 Tahun 1999 tentang Kehutanan (Lembaran Negara Repulk Indonesia Tahun 1999 Nomor 167 Tambahan Lembaran Negara Nomor 3888), sebagaimana telah diubah dengan Undang-Undang Nomor 19 Tahun 2004 tentang Penetapan Peraturan Pemerintah Pengganti Undang-Undang Nomor 1 Tahun 2004 tentang Perubahan atas Undang-Undang Nomor 41 Tahun 1999 tentang Kehutanan menjadi Undang: Undang (Lembaran Negara Republix Indonesia Tahun 2004 Nomor 86. Tambahan Lembaran Negara Nomor 4412);

5. Undang-Undang Nomor 54 Tahun 1999 tentang Pembentukan Kabupaten Sarolangun, Kabupaten Tebo, Kabupaten Muaro Jambi dan Kabupaten Tanjung Jabung Timur (Lembaran Negara Republik 
Indonesia Tahun 1999 Nomor 182, Tambahan Lembaran Negara Republk Indonesia Nomor 3900):

6. Undang-Undang Nomor 32 Tahun 2004 tentang Pemerintahan Daerah (Lembaran Nogara Republik Indonakia Tahun 2004 Nomor 125. Tambahan Lembaran Negara Repubik Indones:a Nomor 4437) sebsgaimana tekah diwbai dengan Undang-Undang Nomor b Tahun 2005 tentang Penetapan Peraturan Penerintah Pengganti Undang- Undang Nomor 3 Tahun 2005 tentarg Perubahan atas Undang- Undang Nomor 32 Tahun 2004 tentang Pomerintahan Daerah menjadi Undang Undang (Lembaran Negara Republik Indonesia Tahun 2005 Nomor 100, Tambahan Lembaran Negara Repubik Indonesia Nomor 4546):

7. Undang-Undang Nomor 10 Tahun 2004 tentang Pembentukian Peraturan Perundang-undangan [Lembaran Negara Republik Indonesia Tahun 2004 Nomor 53. Tambahan Lembaran Negara Republik Nomar 4389y.

8. Undang-Lndang Nonor 12 Tanun 2004 bentang Pemerintahan Daerah (Lembiran Negara Repu blik Indonesia Tahun 2004 Nomer 125. Tambahan Lembaran Negara Pepubik Indonedia Nomor 4437) dobgaimana telah diubah dengan Peraturan Pemerintahan Pengganti Undang-Undang Nomor 3 Tahun 2005 tentang Perubahan Atas Undang-Undang Nomor 32 Tahun 2004 tentang Pemerintahan DarrahiLembaran Negara Republis Indonosia Tahun 2005 Nomor 39, Tambahan Lembaran Negara Republik Indonesia Nomor 4493) yang tolah ditetapkan dengan UndangUndang Nomor B Tahun 2005 (Lembaran Negara Republk Indonesia Tahun 2005 Nomor 106, Tambahan Lembaran Negara Pepubik Indontesia Nomor 4549 i:

9. Undang-Undang Nomor 313 Tahun 2004 inentang Perinbangan Keuangan Antaru Pemeriah Pusat dan Pemerintahan Davah (Lembaran Negara Republk Indonesia Tahun 2004 Nomor 126. Tambahan Lembaran Negara Republik lndonetia Nomor 4438);

10. Undang-Undang Nomor 26 tahun 2007 tentang Penataan Ruang (Lembaran Negara Republik Indonesia Tahun 2007 Nomor 4 A Tambahan Lembaran Negara Nomor 4833j.

11. Peraluran Pemerintah Nomor 25 Tahun 2000 teniang Kewenangan Pemenintah dan Kewenangan Provinsi sebagail Daerah Cocoiom (Lembaran Negara Republik Indonesia Tahun 2000 Nomor 54 Tambahan Lembaran Negara Republik Indonesia Nomor 3852);

12. Peraturan Pamerintah Nomor 72 Tahun 2005 tentang Desa (Lembaran Negara Republik Indonesia Tahun 2005 Nomor 158. Tambahan Lembaran Negara Republik Indonesia Nomor 4587]

13 Peraturan Pomerintah Namor 6 Tahun 2007 tentang Tata Hutan dan Penyusunan Rencana Pengelolagn Hutan, serta Pemantaatan Hutan sebagaimana telah dubah dengan Peraturan Pemerintah Nomor 3 Tahur 200a;

14. Peraturan Mnteri Kehulanan No 49 Tahun 2008 Tentang Hutan Desa

15. Keputusan Menteri Dalam Megeni Nomor 48 Tahun 2002 ientang Teknik Penyusunian Peraturan Desa dan Kepulusan Kepala Desa:

16. Peraturan Daarah Kabupaten Bungo Nomor 22 Tahun 2000 tentang Peraturan Desa (Lembaran Daerah Kabupaiten Bungo Nomor 21 Seri o Tahun 2000i: 
Dengan Persetujuan Ber:ama

BADAN PERIAUSYAWARATAN DUSUN LUBUK BERINGIN

DAN

RIO DUSUN LUBUK BERINGIN

MEMUTUSKAN

Menetapkan

Kesatu : Mengesahkan Kelompok Ndendang Hulu Sako - Batang Buat sebagaimana terlampir scbagai Lembaga Pengelola Hutan Desa Lubuk Beringin kecamatan Bathin III Ulu kabupaten Bungo

Kedua : Peraturan Desa ini mulai berlaku pada tanggal diundangkan. Agar setiap orang dapat mengetahuinya, memerintahkan pengundangan Peraturan Desa ini dengan penempatannya dalam Berita Daerah Kabupaten Bungo.

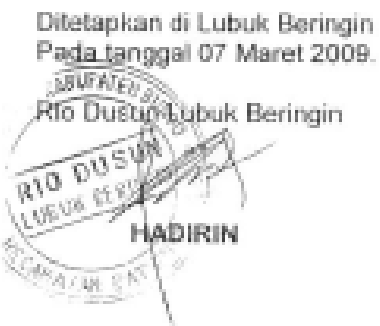

LAMPIRAN 1.

SUSUNAN PENGURUS

KELOMPOK NDENDANG HULU SAKO - BATANG BUAT

DUSUN LUBUK BERINGIN KECAMATAN BATHIN III ULU

KABUPATEN BUNजิO

$\begin{array}{ll}\text { Ketua } & \text { : Muklis } \\ \text { Sekretaris } & \text { : Muslimin } \\ \text { Bendahara } & \text { : Kabri }\end{array}$

L. Seksi Pengamanan Kawasan Hutan Desa Koordinator : Baihaki

Anggota

a. Hadari

b. M. Juri

c. Solhan

II. Seksi Pengamanan Kawasan Hutan Desa Koordinator : Aljupri

Anggota

a. Heimi

b. Haryadi Batubara

c. Zulkifi 


\title{
Attachment 4
}

\author{
Nomor : ODILMDES-HDLB,0J2009 \\ Lampiran : 1 (astu) borkas \\ Hal :Permohonan Hak Pongelolaan Huton Desa \\ Kopada Ytit \\ Bapak Bupati Bungo \\ di \\ Muara Bungo
}

Lubuk Berimgin, 20 Maret 2009

Assalamualaisum Wr. Wb

Kami senantiasa mandoakan semoga Bapak sonantisa dalam lindungan-Nye dan salalu sukses dalam malakeanakan lugas serla aktifitas sthari-hari. Amicn. Ya Robbal Alamin.

Menujuk kepada Peraturan Menteri Kehutanan Repulik Indonckia Nomor P-49 Menhut-IIV008 tentang Hutan Desa dan SK. Menieri Kehulanan No: 109MonhutIrroog Tentang Penetapan Areal Kera Hulan Deria Pada Kawasan Hutan Lindung Bukit Panjang Rantaı Bayur Beluas 2365 Ha yang Terktak Dalam Wilayah Adniniatrasi Dusun Lubuk Beringin Kacamatan Bathin III Ulu Kabuputen Bungo. Kami sebagai Lembaga Desa pengelola Hutan Desa yang dilelapkan berdasarkan Peraturan Desa Dusun Lubuk Beringin No: 01 Tahun 2009 tentang Kelompok Ndendang Hulu Sako Batang Buat, menqujukan pemohonan untuk mendapakan Hak Pengelolaan Hulan Dosa Dusun Lubuk Beningin. Keberadaan kawasan hutan desa diwlayah kami sangal penting, karena kwwasan tersebut berfungsi sobagai hulu DAS Batang Buat. Dimana terjaganya kiwasan tersebut skun memberikan manfaat langsung bogi desa kami, yaitu terjaganya sumber air yang dapa: mengairi suwsh, menggerakkan pembangkit lisitrik ionago kincir aif, sumber air minum, tempat pemijahan ikan dan sebageinga.

Domikianlah permohonan ini kami sampaikan. Besal harapan kami Bopak sudi memberikan paratujuan dan dukingan. Atas perkenan dan kegediaan Bapak. kam haturkan terimakasih.

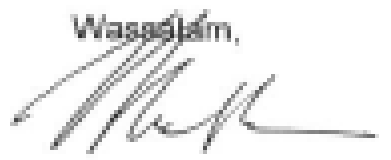

\section{Mukhils}

Ketua Kelompok Ndendang Hulu Sako Ealang Buat

Tembusan disampaikan kepada Yih:

1. Bapak Kepala Dinas Kehulanan dan Perkebunan Kabupaten Bungo

2. Bapak Camat Kecsmatan Bathin III Uilu

3. Arsp

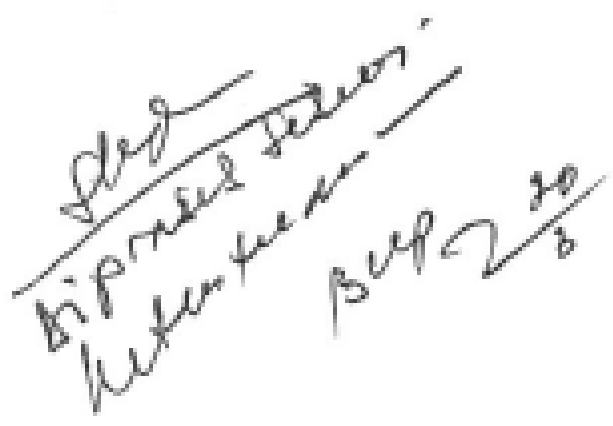


Attachment 5

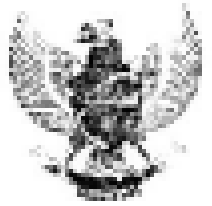

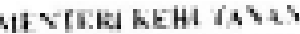

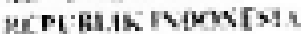

\section{KEPUTUSAN MENTERI KEHUTANAN}

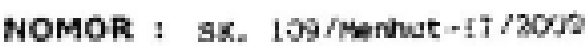

TENTANG

PENETAPAN AREAL KERUA HUTAF DESA PADA KAWASAN HUTAN LINDUNE BUKIT PANOANG RANTAU BAYUR SELUAS \pm 2.356 (DUA RIBU TIGA RATUS LIMA PULUH ENAM) HEKTAR TERLETAK DALAM WILAYAH ADMINISTRASI DUSUN LUBUK BERINGIN, KECAMATAN BATHIN III ULU, KABUPATEN BUNGO, PROVINSI JAMBI

\section{MENTERI KEHUTANAN,}

Menimbang

a. bahwa berdasarkan Pasal 86 arat (1) Feratuan Pemerintal Nombi 6 Tahuin 2007 sebagalmana telgh divbaht dengan Peraturan Pemerintah Nomor 3 Tahun 2008 tentang Tata Hutan dan Penyusunan Aencana Pengelolaan Huran Serta Pemanfatan Hutan, Menteri manetapkan areal keja hutan des!

b. bahwa berdasankan Pasal 4 ayat (1) Peraturan Menteri Kehutanan Nanor P.49/Menhut-[/2008 tentang Hutan Desa. kiteria kawasan hutan yang dapat ditetapkan olefi Menteri berada pada kawasan hutan lindung dan hutan produkp yang belum dibebuni hak pengeloloan atau izh pemanfatan; dan berada dolam wilsyah administrasi desa yang bersangkutan;

5. buhwa berdasarkan Pasal 7 Peraturan Mentari Kehutanan Nomor P.49/Menhut-II/2008 dan Keputusan Merteri Kehutanan Nomor SK.76/Menhut-II/2009 tentang Tin Verifikasi Hutan Desa, telah dlakukan Verfikasi Huhan Detsa pada kawasan Hutan lindung Bukit Panjang Rentau Bayur di Dusiun Lubuk Eeringin Kecamatan Eathin III Uis Rabupsten Bungo Provinsi Jambi, vang diusulkan Bupati Bungo dengan surat no. $522 / 2312 /$ Hutbun terggal 17 Desember 2008. 
d. bahwa berdasanan pertinbangan tersabut ditss, dan mempertatikan hasil Verifikasi, dipandand periu mentapkan Keputusan Menteri Kehutanan tentarg Penetapan Areal Korja Hutan Desa pada Kowacan Hutan Lindung Bubit Panjang Rantau Borur seluas \pm 2.355 (du's ribe tiga ratus ling puluh enam) hektar tertetik dalam wilaysh administras Dusun Lubuk Beringin, Ketentiten Bsthin III Ulu, Kabupaten Bungo, Fovingi Jambi.

Mengingat

1. Undang-Lindang Nomor 41 Tahua 1995 enlang Kehutanan

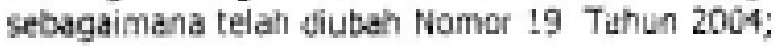

2- Undang-Undang Nomor 32 Tyhuñ 2004 tentang Pdmerintahan Daerah;

3. Peraturan Pemerintah Nomor 6 Tahun 2007 sebegaimana telah dhubah dengen Peraturan Pemerintah ho 3 Tahun 2006 tentang Tata Hutan dan Penyusunen Rencana Pengelolaan Hutan, serta Petnanfabtan Hutan;

4. Feraturan Pemerintah Nomer 38 Tahun 2007 tantang Pembagian Urusan Pemerintahan antara Pesmerintah, Pernerintahan Dserah Provinsi dan pemerinlaheil Daerah Kebupetenv/Kata:

5. Peraturañ Peinerintah Namor 76 Tahun 2008 tentang Rehabilitasi dan Reklamasi Hutan:

6. Keputusan Presiden Nomer 187/M Tahun 2004 teriang Pembentukan Kabinet Indonesia Bersotu sebsgaimang telah beberapa kali diubah terakhir dengan Nomos 31/P Tahun 2007!

7. Peraturan Presiden Republik Indonesia Namor 9 Tahun 2005 tentang Kedudukan, Tugas, Fungsi, Suswnan Organsasi, dan Tata Kerja Kementrian Negara Repubik Indonesia enbagaimana telah beberapa lali diubah terakhir dengan Nomor 90 Tahun 2006:

8. Peraturan Presiden Nomor 10 Tahun 2005 tentang Unt Organisasi dan Tugas Eselon I Kementrian Negara Republik Indonesla sebagaimana telsh beberapa kall dubah terakhir dengan Nomor 17 Tahun 2007 ; 
Mempenatikan

\author{
Henetopkin
}

KESFIU

REDUA

KETIGA

REEMPAT

KELIMA

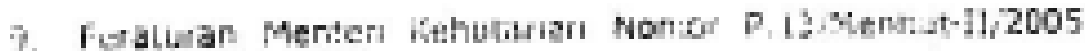

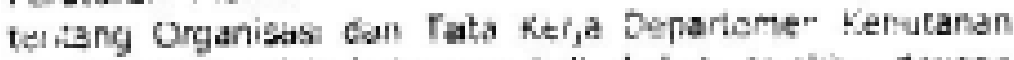
souagimand telat bebrapa kli dubah brakh derigan

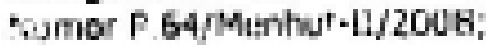

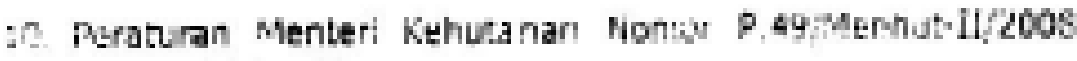
uindang Hutan Dewa.

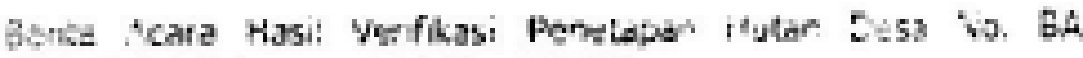

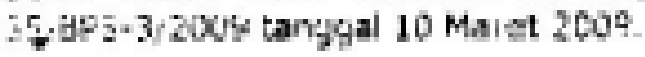

\section{MEMUTUSKAN :}

Merebowan Arco Keja Hutan Des pads havasan Hutar Lindung Bukt Panjang Pantau Eayur seluas + 2.35t pua rou tqa btus lima puluh eriam hektar terletas dolan widph dohmostras Dusin Lubuk Berngin, Keramatan Banci [I: Ulu, Kabuputen Bungo, Provinsi jambi.

Lokasi kamasan hutan dest sebacainand dimakiud amar PERTMMA adalah sebagaimana terlukis pada peta Iampiran Keputuran ini.

: Peretepan Areal Kerja Hutan Drsa shbagpimana amer PEATAMA todk merubah status dan fungel hwasan sobogal Hutdn Lindung.

; Ponetapan Areal Kerja Huban Dewa sebogeimsne omar PERTAMA digunakan sebogal dasar Pemberian Hak Pengelolesn Hutan Desa dith Gubarmur kepada lembaga deca Lubuk Benngin, Kecsmiban Bathin III Ulu, Kabupaten Bungo Provins! Jambi saluai ketentuan peraburan perundang-undangan.

Dalam pernbersn hak pengeloloan huban dese, Gubenur berpodoman poda Peraturan Menteri Kehutanañ No. P. 49/Henhut-I/2004 tentang Hutan Desa den petunjus pesabunaanmy. 
KEENAM : Denoan adariyd penetapan areal kerja hutari desa tersebut pada Jinar KESATU, lembaga desd Lubuk Beringin, Kecamatan Bathin III Ulu, Kabupaten Bungo Provinsi lambi berkewajiban untuk mengawasi batas dan tanda batas hutan desa sebagaimana amar KEDUA.

KETUJUH Dalam penystenggaraan pengelolasn hutan desa, Bupat: berkewajiban melakukan sosialisasi, fas/ritasi, bimbingan dan pembinsan kepada lembaga desa sesual ketentuan Pcraturan Menteri Kehutanan No. P.49/Menhut-11/2008 tentang Hutan Desa dan petunjuk pelaksanaannya.

KEDELAPAN : Keputusan ini mulai berlaku pada tanggal ditetspkan,

Ditetapkan di : Jakarta

Pada tanggal :17 Varuz 2009

Salinen sesuai dengan aslinya Kepalz Bijo Hukum dan Organisasi,

MENTERI KEHUTANAN

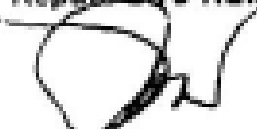

Ttd

SUPKRO, SH

H. M. S. KABAP

NIP/19500514 1983031001

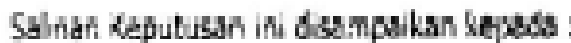

1. Menteri Dalam Negeri

2. Menten Pertanian

3. Nenteri Energi dan Sumberdaya Mineral;

4. Menteri Negara Lingkungan Hidup;

5. Menteri Negard Perencanaan Pembangunan Nasional/Kepala Bappenas;

6. Kepala Badan Pertanahan Nasional

7. Menteri Koperasi dan Usaha Keol Menengah

8. Gubernur Jambi

9. Bupati Bungo

10. Pejabat Eselon I lingkup Departemen Kehutanan

11. Kepala Pusat Pengendalian Pembaingunan Kehutanan Regional I;

12. Kepala Dinas Kehutanan Provinsi Jambl;

13. Kepala Dinas Kehutanan dan Perkebunan Kabupaten Bungo;

14. Kepala Balai Pemantapan Kawasan Hutan Wilayah XuI Tanjung Pinang; 15. Kepa/a Balai Pengelolaan DAS Batanghar. 


\title{
Attachment 6
}

\section{PEMERINTAH KABUPATEN BUNGO KECAMATAN BATHIN III ULU DUSUN LUBUK BERINGIN}

Lubuk Beringin, 5 November 2008

\author{
Nomo $\quad 32 / \mathrm{Ds} / \mathrm{Lb}$ N/2008 \\ Lampiran : 1 (satu) berkas \\ Ha : Permohonan Penetapan Areal Kerja Hutan Desa \\ Kepada Yth: \\ Bapak H. Zulfikar Achmad \\ Bupati Kabupaten Bungo \\ di \\ Muara Bungo
}

Assalamualaikum Wr. Wb

Kami senantiasa mendoakan semoga Bapak senantiasa dalam lindungan-Nya dan selalu sukses dalam melaksanakan tugas serta aktifitas sehari-hari. Amien. Ya Robbal Alamin.

Kami masyarakat Dusun Lubuk Beringin, Kecamatan Bathin III Ulu, Kabupaten Bungo, selama ini telah melakukan kegiatan pengelolaan hutan secara arif dan lestan. Pengelolaan yang kami lakukan dengan menggunakan aturan adat yang telah berjalan turun temurun, ternyata mampu menjaga kelestarian kawasan hutan. Beberapa aturan terkait yang mendukung juga telah lama kami sepakati dan terapkan, seperti aturan menjaga kawasan hutan lindung. kawasan agroforest karet dan lubuk larangan sebagai sumberdaya alam desa yang tertuang didalam kesepakatan konservasi desa yang isinya antara lain berbuny "Masyarakat sepakat untuk tidak mengolah lahan-lahan pertanian secara terus menerus (behumo) pada lahan-lahan miring/curam, pinggir sungai, dan hulu-hulu KA $P$ H, tidak terganggu". sungai supaya tidak terjadi longsor, banjifferosi, atau sumber pengairan sawah

Keberadaan kawasan hutan Lindung Rantau Bayur sangat penting bagi kami, karena sebagai kawasan hulu DAS Batang Buat. Dimana terjaganya kawasan tersebut akan memberikan manfaat langsung bagi desa kami, yaitu terjaganya sumber air yang berhulu pada kawasan hutan lindung dan sgroforest karet, sehingga tetap dapat mengairi sawah, menggerakkan pembangkit listrik tenaga kincir air , sumber air minum, tempat pemijahan ikan dan sebagainya. Upaya yang kami lakukan telah memperoleh pengakuan dan dukungan para pihak, di mana Dusun Lubuk Beringin telah menerima penghargaan Kalpataru tingkat Propinsi Jambi. Sayangnya kawasan tersebut saat ini tengah terancam oleh sop kegiatan konversi dan perambahan hutan oleh masyarakat dari luar wilayah hemiem? kawasan dengan prinsip keberlanjutan fungsi ekosistem kawasan tersebut,

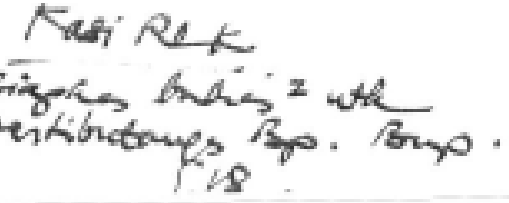


Stalan dangan telah keluarnya Peraburan Menteri Kehutaran No. P_dGhlentut .

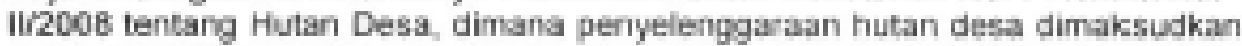
unilk menberikan akses kepoda masyarakes seimpat melalui lembaga drea dabun memanfaskan sumberdayj hutan secara lostari dan meningkathan

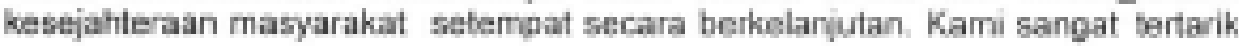
untuk mengimphamantasikan konsop tersebut sabagal upaya kami unbu menjaga kswasan hutan yang tersica dil sakitar dosa.

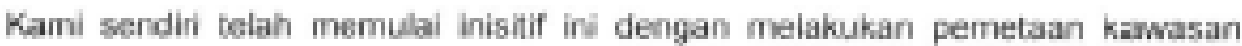
yang akan diusukan yaitu didalam Kawasan Hulan Lindung Rantau Bayu soluas 2356 Hektar, periguatan kelembagaan lokal yang akan menjadi lembaga pengelcla areal korja hutan dosa dan telah membahas aspirasi masyarakat terhail dengan ahuran pangeblasonya. Kami juga tebh difasilitaci obh bortagal phak bak dafi KKI WAFSI, ICRAF dan Dinas Kahubanan dan Parsebunan Kabupaken Bungo.

Obh karena ilu kami memohon agar Bapak bisa nenelapkin areal tersobut sobagi areal kerja Hutan Dosa Dusun Lubuk Beringin Keciamatan Bathin Ill Ulu Kabupaten Bungo. Sabagal belangkapan paryaratan hami Iampikan pela usulan hutan daka dan gambaran fondisi kawacan hutan yang kami ugulkan.

Demikianlah pemohanan ini kari sampakan. Besar harapan kami Bapak sud memberkan prso"ujuan dan dukungan. Abs perkenan dan kesedaan Bapas. karril halukan torinakash.

Wasgakam.
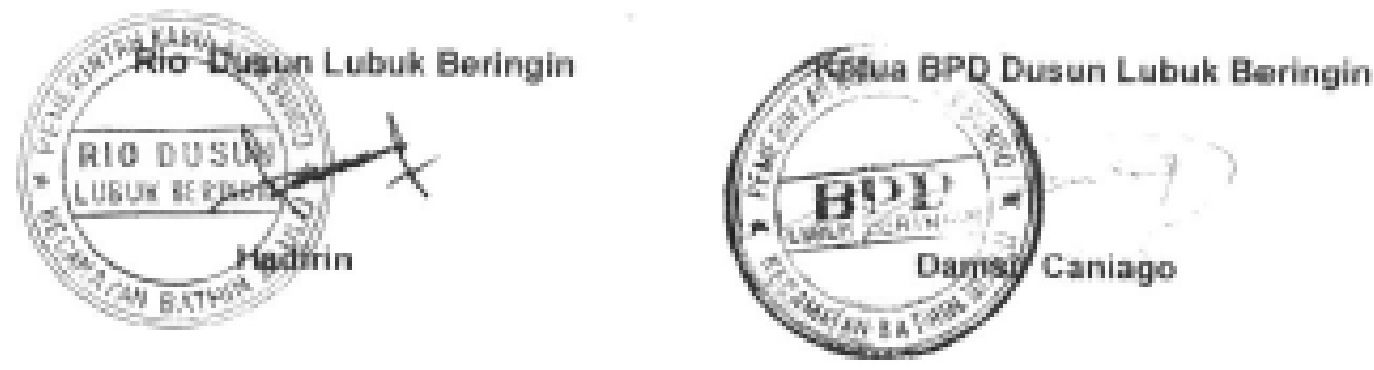

Tembuan disampaikan kepada wT:

1. Bapak Kepala Dinas Kehutanan don Perkebunan Kabupaken Bungo

2. Bapak Camat Kecumalan Bathin III Ulu

3. Arsip 


\section{Attachment 7.}

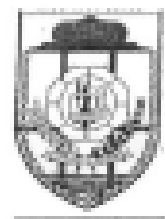

\section{PEMERINTAH KABUPATEN BUMGO \\ DINAS KEHUTANAN DAN PERKEBUNAN}

J. R.M. Thather No 60 ? Rimbo Tengah Telp. (0747) 214.44 Fax. (0747) 21473

MUARA BUNGO

\section{NOTA DINAS}

\begin{tabular}{|c|c|c|}
\hline Kepada Yth & : & Bupak Bupati Bungo \\
\hline Melalui Yth & : & Bapak Sekretaris Daerah Kabupaten Bungo \\
\hline Duri & & Kepala Dinas Kehutanan dan Perkebunan Kabupaten Bunge. \\
\hline Nomar & ; & $522 / 899$ / Hubun \\
\hline Lempiran & : & 1 (satu) berkas \\
\hline Perihal & $\approx$ & $\begin{array}{l}\text { Pertimbangan Tehnis ieshadap Permohonas Penetapan Areal Kerja Hutan Desa } \\
\text { Dusun Lubuk Beringin Kecanatan Bathin III Ulu. }\end{array}$ \\
\hline Tanggal & : & Desember 2008 \\
\hline
\end{tabular}

Dengan hormat,

Bersuma ini dapat Kami sampaikan pertimbanyaa tehnis terhadap permohonan dari Rio Dusan Lubuk Beringin dan Ketua BPD Dusun Lubuk Beringin berdesarkas surat Nower 32/Ds/Lb/2/200s tanggal 05 November 2008 perihal Permohonan Pexcetapan Areal Kerja Hutas Desa, sebagai berikut :

1. Masyarakat Dusun Lubuk Berizgin Kecamatan Buhin III Uha mengajukan permohonan penetapan araal kerja Hutan Desa pada Kawasan Hutan Lindung Bukit Panjang Rantau Bayur scluas \pm 2.356 ha.

2. Secara administrasi pemenintahan, kawasan hutan lindung tersebut berada di Kecamatan Bathin III Ulu dan berdasarkan sdministrasi kelumtanan, masuk dalam wilayah kerja Dinas Kehutanin dan Perkebunan Kabupaten Bungo.

3. Kondisi Kawasan Hutan Lindung Bukit Panjarg Rartas Bayur tersebut maxih sangat baik dengan lopografi berbukit. Kawasan tersebut juga mempunyal tungai hidrologi yang penting artinya bagi desu - desa disekitar kawasan secara khusus dan Kabupsiten Bungo secara umum, untuk menjagg kestabilan tals air, mencegah terjadinya bencana bujjir dan tanah longsor, wencegah erosi serta memelihara kesuburan tanah. Selsin itu juga, sumber air yang mengalir dari dalam kawasan Hutan Lindung dapot berfungsi uxatuk sumbar air minum, sumber conergi umuk pembangkit listrik tenaga kincir air serta samber pengairan sawah.

4. Kawasan Hutan Lindung tersetut juga mempunyai keasekaraganan hayati yaae tingei serta menjadi tenspat hidup bagi flora das fauna.

5. Berdasarkan data yang ada pada Dinas Kehutanan dan Perkebunan Kabupanen Bungo, Kawasan Hutan kersebut ditetaptan menjadi Hutan Lindung Bukil Pajjang Rantau Bayur bendasarkan Keputusan Menteri Kehutanan RI Nomor 421/Kpts-[U/1999 tangeal IS Juni 1999 ketang Penunjukan Kawasan Hutan Provinsi Jambi serta tidak terdagat perizinan ci dalom kawasan hutan tersebut.

6. Beberapa pengertian yang dapa, Kami sampaikan kepada Bapk Bupati terkait dengan twsulin misyarakat. Dusun Lubuk Beringin , adalah :

a. Kawasan Hutan adalah wilaysh terientu yang ditunjuk dan' ditetapikan olet Perserintah untuk dipertahankas keberadannya sebagai hutan tetap.

b. Hutan Lindung adalah kawasan hutan yane mempunyai fingsi pokok sebagai perlindungan sistem penysogen kebidepra unter mengatur twa air, mencegah banjir, mrgendwilan enct, neoceget int-ixi air laut das memelihara kesuburas tanah. 
c- Hoim Desa adalah huin Nepara yang dikelola olch Desa dan dincanfuntkan uniuk kescjuhteran desa geria belun cibebari sinhat.

d. Areal kerja hutan dosa adalah satu kesatuan bamparan kawasun hutan yang dapat dikekola olleh lentuga desa secara legtari.

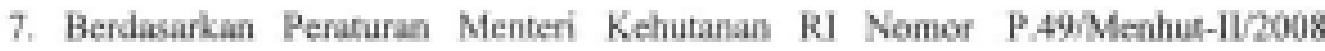
tanggal 25 Agustus 200 sentang. Hutan Desa, padr Bagian Kedua pasal 5 disebukan buhwe Penetapan areal kejpa bulan desa dilakukan oleh Menkeri berdasarkan usulan BupaijWalikota, Selunjutnja dalan pasal 6 ayat (1) dishotkan bahwa BupatirWalikota mengusulkan penetupan areal kerja buian desa kepada Menteri berdasarkan permohonan Kepala desa dengan dilampiri pesa

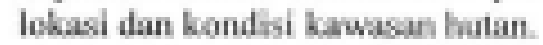

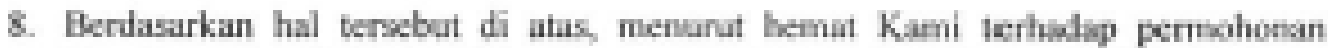
Penapain Areal Kerja Hulan Desa okeh Masyarakat Deran Lubuk Beringin Kecamatan Buhis III Uth, depat ditenukin kepoda Menteri kehutanan RT oleh Bapak Bupati Bungo.

9. Untuk inu, Kami mobon agar Bapak Bupai dopar maminduingani arat pengusulan kepada Menieri Kotwhinan RU atas asmohonan Peneinpan Areal Karja Hulan Desa Dusun Lubuk Beringin Keckmisa: Buthin III Ulu.

Denikian, abas perhstian das perkenaun Bupek, Kam uspkan te rima kasih.

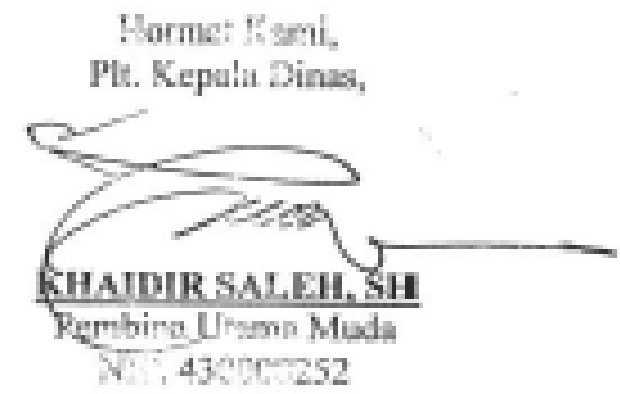




\section{Attachment 8}

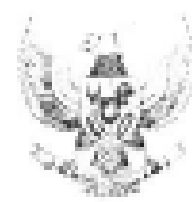

\section{BUPATI BUNGO}

$\begin{aligned} & =522 / 23 / 2-\text { Hutbun } \\ \text { Nomor } & =- \\ \text { Lampiran } & =\text { Ueukn Penefopan Arear keva } \\ \text { Perihal } & \text { Hutam Dosa }\end{aligned}$

\section{Mused Bungo, 17 Desember 2008 \\ Kepada \\ Yth. Menteri Kehutanan RI}

di .

$$
\text { JAKARTA }
$$

Dengan hormat,

Setrubungan dengan surat Rio Dusun Lubuk Beringin dan Ketua BPD Dusun Lubuk Beringin (atas nama Masyarakat Dusun" wouk Berimgin) berdasarkan surat Nomor 32/Ds/Lb/V/2008 tanggal 05 Nowember 2008 penhal Permohonan Penetapan k.eal Kerja Hutan Desa dan berpedoman kepada :

1. Undang-undang RI Namar 41 tahun 1999 temang Kehuitanan,

2. Peraturan Pemerintah Nomar 33 Tahun 2002 temtang Perencanaan Kehutanan,

3. Peraturan Pemerintah Nomor 45 tahun 2004 tentang Perindungan Hutan,

4. Peraturan Pemerintah Nomor 6 tahun 2007 tentang Tata Hivan dall Rencana Pengeiolaan Hutan serta Pemanfaatan Mutan

5. Surat Keputusan Menten Kehutanan dan Perkebunan RI Nomar 421/Kpts-[L/1999 tanggal 15 Juni 1999 tentang Penunjukan Kawasan Hutan Provinsi Jambi,

6. Peraturan Menteri Kehutanan Namor P,49/Menhut-11/2008 tentang Hutan Desa.

Dapat dsampakan bahwa Pemerintah Kabupaten Bungo sangat menđukung terhadap usulan dari Masyarakat Dusun Lubuk Beringin Kecamatar Bathin III Ulu untuk mendapatkan hak pengeiolasn hutan desa dan mengusulkan kepada Menteri Ketutanan Rl untuk mendapatkar Penetapan Areal Kerja Hutan Desa Dusun Lubuk Beringin Kecamatan Bathin III Ulu seluas 2.356 hektar yang terletak di dalam Kawasan Hutan Lindung (HL) Bukit Panjang Rantau Bayur Kelompok Hutan Merangin Alai Kabupaten Bungo Provinsi Jambi.

Teriampir dasmpaikan Peta Usulan Aveal Kerja Hutan Desa Dusun Lubuk Beringin Kecamatan Bathin 111 Ulu Skala 1 ; 50.000 dan kondsi Kawasan Hutan Lindung (HL) Eukit Panjang Pantau Bapur.

Demiklan diampaikan untuk menjadi bahan pertimbangan selanjutrro.

TEMBUSAR:

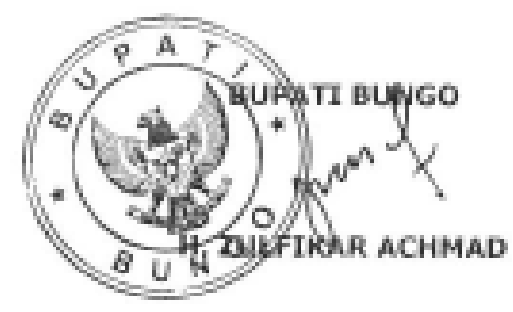

1. Ych. Gubermur Jarnbi

2. Yth. Direktur Jendoral Rehabilitasi Lahan dan Pertutanan Sosial Dephut

3. Yth. Kepala Badan Planologi Departemen Kehutanar

4. Yob. Kepala Dinas Kehutanan Prowirsi Jambi

5. YUn. Kepala Dinas Kethutarnar dor Perkebunan Kabupaten Bungo

6. Yth. Kepala Balai Penantapan Kawasan Hutan (BPKH) Wilyah X11I Pangkal Pinang

7. Yth. Camat Bathin III Ulu

8. Thi. Rie Dusun Lubuk Berinain 


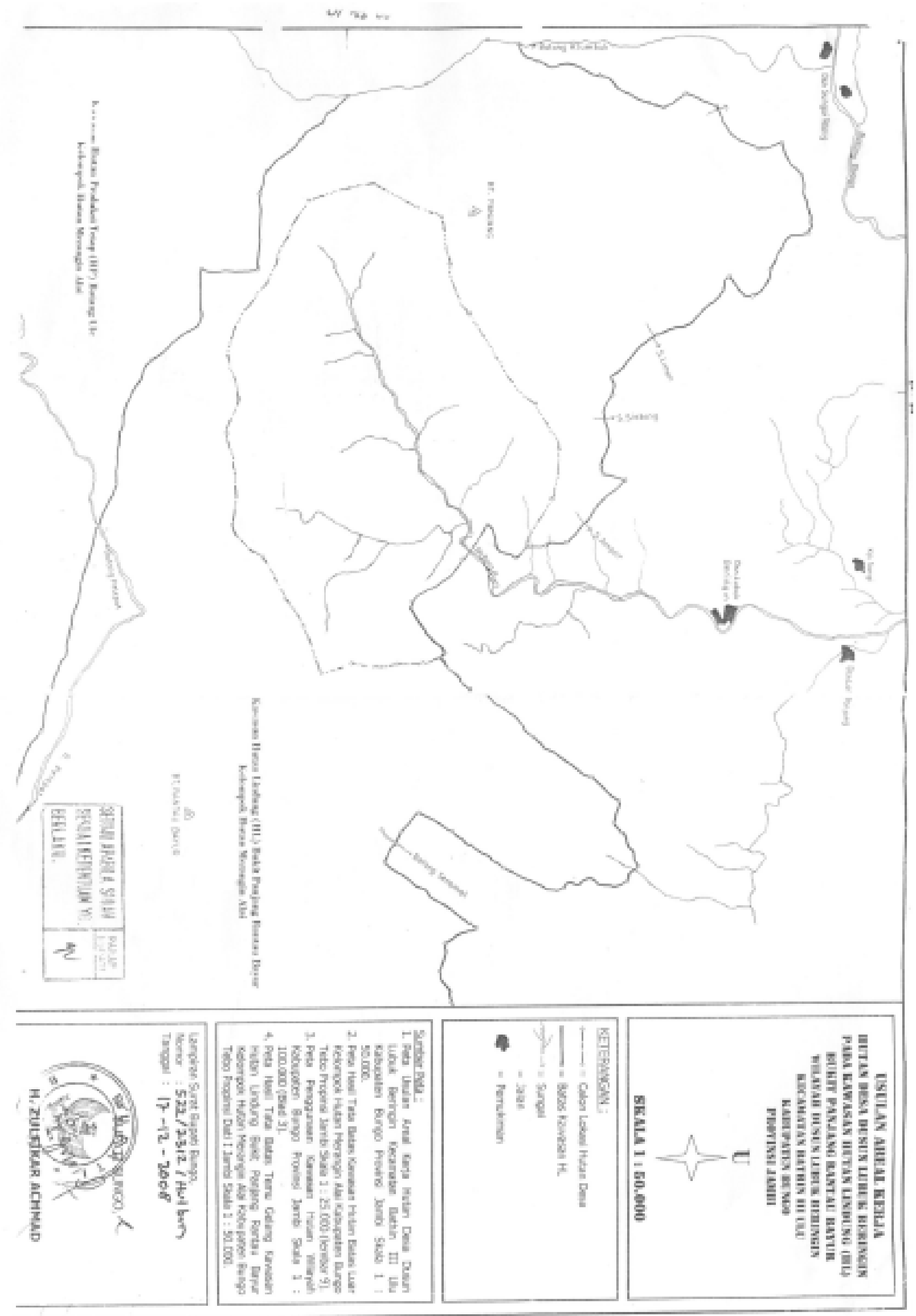




\section{Attachment 9}

\section{SURAT PERNYATAAN KEPALA DUSUN}

Yang bertandatangan di bawah ini :

Nama : HADIRIN

Jabatan : Kepala Dusun/Rio Lubuk Beringin

Sehubungan dengan usulan Penetapan Areal Kerja Hutan Desa kepada Bupati Bungo ciengan surat kami nomor $32 / \mathrm{Ds} / \mathrm{Lb} / \mathrm{V} / 2008$ tanggal 5 November 2008 perihal Parmohonan Penelapan Areal Kerja Hutan Desa.

Dengan ini menyatakan komitmen atas hal-hal sebagai berikut :

1. Bersama worga masyarakat desa bersedia melestarikan fungsi hutan dari Areal Kerja Hutan Desa yang diusulkan menjadi Hutan Desa

2. Tidak akan melakukan perubahan status dan fungsi hutan dari kawasan hutan yang diusulkan unfuk menjadi Hutan Deso

3. Akan segera membentuk lembagd desa sebagai pengelola Hutan Desa.

Demikian, pernyatoan ini kami buat secara sungguh-sungguh.

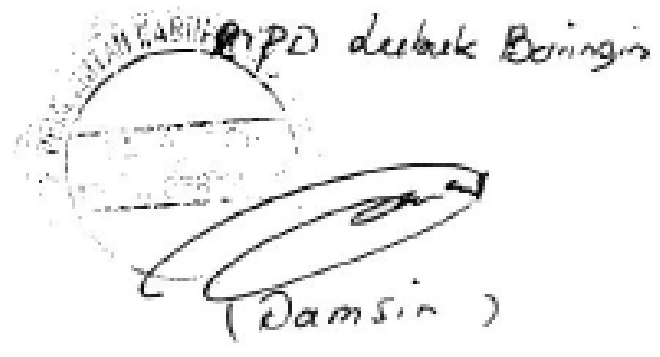

Dusun Lubuk Beringin. 07 Maret 2009 Pembuat Pernyataan

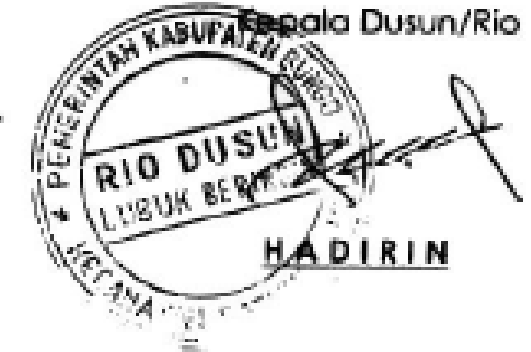




\section{WORKING PAPERS IN THIS SERIES}

2005

1. Agroforestry in the drylands of eastern Africa: a call to action

2. Biodiversity conservation through agroforestry: managing tree species diversity within a network of community-based, nongovernmental, governmental and research organizations in western Kenya.

3. Invasion of prosopis juliflora and local livelihoods: Case study from the Lake Baringo area of Kenya

4. Leadership for change in farmers organizations: Training report: Ridar Hotel, Kampala, 29th March to 2nd April 2005.

5. Domestication des espèces agroforestières au Sahel : situation actuelle et perspectives

6. Relevé des données de biodiversité ligneuse: Manuel du projet biodiversité des parcs agroforestiers au Sahel

7. Improved land management in the Lake Victoria Basin: TransVic Project's draft report.

8. Livelihood capital, strategies and outcomes in the Taita hills of Kenya

9. Les espèces ligneuses et leurs usages: Les préférences des paysans dans le Cercle de Ségou, au Mali

10. La biodiversité des espèces ligneuses: Diversité arborée et unités de gestion du terroir dans le Cercle de Ségou, au Mali

11. Bird diversity and land use on the slopes of Mt. Kilimanjaro and the adjacent plains, Tanzania

12. Water, women and local social organization in the Western Kenya Highlands

13. Highlights of ongoing research of the World Agroforestry Centre in Indonesia

14. Prospects of adoption of tree-based systems in a rural landscape and its likely impacts on carbon stocks and farmers' welfare: The FALLOW Model Application in Muara Sungkai, Lampung, Sumatra, in a 'Clean Development Mechanism' context

15. Equipping integrated natural resource managers for healthy agroforestry landscapes.

16. Are they competing or compensating on farm? Status of indigenous and exotic tree species in a wide range of agro-ecological zones of Eastern and Central Kenya, surrounding Mt. Kenya.

17. Agro-biodiversity and CGIAR tree and forest science: approaches and examples from Sumatra.

18. Improving land management in eastern and southern Africa: A review of polices.

19. Farm and household economic study of Kecamatan Nanggung, Kabupaten Bogor, Indonesia: A socio-economic base line study of agroforestry innovations and livelihood enhancement.

20. Lessons from eastern Africa's unsustainable charcoal business.

21. Evolution of RELMA's approaches to land management: Lessons from two decades of research and development in eastern and southern Africa

22. Participatory watershed management: Lessons from RELMA's work with farmers in eastern Africa.

23. Strengthening farmers' organizations: The experience of RELMA and ULAMP. 
24. Promoting rainwater harvesting in eastern and southern Africa.

25. The role of livestock in integrated land management.

26. Status of carbon sequestration projects in Africa: Potential benefits and challenges to scaling up.

27. Social and Environmental Trade-Offs in Tree Species Selection: A Methodology for Identifying Niche Incompatibilities in Agroforestry [Appears as AHI Working Paper no. 9]

28. Managing tradeoffs in agroforestry: From conflict to collaboration in natural resource management. [Appears as AHI Working Paper no. 10]

29. Essai d'analyse de la prise en compte des systemes agroforestiers pa les legislations forestieres au Sahel: Cas du Burkina Faso, du Mali, du Niger et du Senegal.

30. Etat de la recherche agroforestière au Rwanda etude bibliographique, période 19872003

31. Science and technological innovations for improving soil fertility and management in Africa: A report for NEPAD’s Science and Technology Forum.

32. Compensation and rewards for environmental services.

33. Latin American regional workshop report compensation.

34 Asia regional workshop on compensation ecosystem services.

35 Report of African regional workshop on compensation ecosystem services.

36 Exploring the inter-linkages among and between compensation and rewards for ecosystem services CRES and human well-being

37 Criteria and indicators for environmental service compensation and reward mechanisms: realistic, voluntary, conditional and pro-poor

38 The conditions for effective mechanisms of compensation and rewards for environmental services.

39 Organization and governance for fostering Pro-Poor Compensation for Environmental Services.

40 How important are different types of compensation and reward mechanisms shaping poverty and ecosystem services across Africa, Asia \& Latin America over the Next two decades?

41. Risk mitigation in contract farming: The case of poultry, cotton, woodfuel and cereals in East Africa.

42. The RELMA savings and credit experiences: Sowing the seed of sustainability

43. Yatich J., Policy and institutional context for NRM in Kenya: Challenges and opportunities for Landcare.

44. Nina-Nina Adoung Nasional di So! Field test of rapid land tenure assessment (RATA) in the Batang Toru Watershed, North Sumatera.

45. Is Hutan Tanaman Rakyat a new paradigm in community based tree planting in Indonesia?

46. Socio-Economic aspects of brackish water aquaculture (Tambak) production in Nanggroe Aceh Darrusalam.

47. Farmer livelihoods in the humid forest and moist savannah zones of Cameroon.

48. Domestication, genre et vulnérabilité : Participation des femmes, des Jeunes et des catégories les plus pauvres à la domestication des arbres agroforestiers au Cameroun. 
49. Land tenure and management in the districts around Mt Elgon: An assessment presented to the Mt Elgon ecosystem conservation programme.

50. The production and marketing of leaf meal from fodder shrubs in Tanga, Tanzania: A pro-poor enterprise for improving livestock productivity.

51. Buyers Perspective on Environmental Services (ES) and Commoditization as an approach to liberate ES markets in the Philippines.

52. Towards Towards community-driven conservation in southwest China: Reconciling state and local perceptions.

53. Biofuels in China: An Analysis of the Opportunities and Challenges of Jatropha curcas in Southwest China.

54. Jatropha curcas biodiesel production in Kenya: Economics and potential value chain development for smallholder farmers

55. Livelihoods and Forest Resources in Aceh and Nias for a Sustainable Forest Resource Management and Economic Progress.

56. Agroforestry on the interface of Orangutan Conservation and Sustainable Livelihoods in Batang Toru, North Sumatra.

57. Assessing Hydrological Situation of Kapuas Hulu Basin, Kapuas Hulu Regency, West Kalimantan.

58. Assessing the Hydrological Situation of Talau Watershed, Belu Regency, East Nusa Tenggara.

59. Kajian Kondisi Hidrologis DAS Talau, Kabupaten Belu, Nusa Tenggara Timur.

60. Kajian Kondisi Hidrologis DAS Kapuas Hulu, Kabupaten Kapuas Hulu, Kalimantan Barat.

61. Lessons learned from community capacity building activities to support agroforest as sustainable economic alternatives in Batang Toru orang utan habitat conservation program (Martini, Endri et al.)

62. Mainstreaming Climate Change in the Philippines.

63. A Conjoint Analysis of Farmer Preferences for Community Forestry Contracts in the Sumber Jaya Watershed, Indonesia.

64. The Highlands: A shower water tower in a changing climate and changing Asia.

65. Eco-Certification: Can It Deliver Conservation and Development in the Tropics?

66. Designing ecological and biodiversity sampling strategies. Towards mainstreaming climate change in grassland management.

67. Participatory Poverty and Livelihood Assessment Report, Kalahan, Nueva Vizcaya, the Philippines

68. An Assessment of the Potential for Carbon Finance in Rangelands

69. ECA Trade-offs Among Ecosystem Services in the Lake Victoria Basin.

70. Le business plan d'une petite entreprise rurale de production et de commercialisation des plants des arbres locaux. Cas de quatre pépinières rurales au Cameroun.

71. Les unités de transformation des produits forestiers non ligneux alimentaires au Cameroun. Diagnostic technique et stratégie de développement Honoré Tabuna et Ingratia Kayitavu.

72. Les exportateurs camerounais de safou (Dacryodes edulis) sur le marché sous régional et international. Profil, fonctionnement et stratégies de développement.

73. Impact of the Southeast Asian Network for Agroforestry Education (SEANAFE) on agroforestry education capacity. 
74. Setting landscape conservation targets and promoting them through compatible land use in the Philippines.

75. Review of methods for researching multistrata systems.

76. Study on economical viability of Jatropha curcas L. plantations in Northern Tanzania Assessing farmers' prospects via cost-benefit analysis

77. Cooperation in Agroforestry between Ministry of Forestry of Indonesia and International Center for Research in Agroforestry

78. "China's bioenergy future. an analysis through the Lens if Yunnan Province

79. Land tenure and agricultural productivity in Africa: A comparative analysis of the economics literature and recent policy strategies and reforms

80. Boundary organizations, objects and agents: linking knowledge with action in agroforestry watersheds

81. Reducing emissions from deforestation and forest degradation (REDD) in Indonesia: options and challenges for fair and efficient payment distribution mechanisms

82. Mainstreaming Climate Change into Agricultural Education: Challenges and Perspectives.

83. Challenging Conventional mindsets and disconnects in Conservation: the emerging role of eco-agriculture in Kenya's Landscape Mosaics.

84. Lesson learned RATA garut dan bengkunat: suatu upaya membedah kebijakan pelepasan kawasan hutan dan redistribusi tanah bekas kawasan hutan.

85. The emergence of forest land redistribution in Indonesia.

86. Commercial opportunities for fruit in Malawi.

87. Status of fruit production processing and marketing in Malawi.

88. Fraud in tree science.

89. Trees on farm: analysis of global extent and geographical patterns of agroforestry

90. The springs of Nyando: water, social organization and livelihoods in Western Kenya.

91. Building cpacity toward region-wide curriculum and teaching materials development in agroforestry education in Southeast Asia.

92. Overview of Biomass Energy Technology in Rural Yunnan.

93. A Pro-Growth Pathway for Reducing Net GHG Emissions in China

94. Analysis of local livelihoods from past to present in the central Kalimantan ExMega Rice Project area

95. Constraints and options to enhancing production of high quality feeds in dairy production in Kenya, Uganda and Rwanda

96. Agroforestry education in the Philippines: status report from the Southeast Asian Network for Agroforestry Education (SEANAFE)

97. Economic viability of Jatropha curcas L. plantations in Northern Tanzania- assessing farmers' prospects via cost-benefit analysis.

98. Hot spot of emission and confusion: land tenure insecurity, contested policies and competing claims in the central Kalimantan Ex-Mega Rice Project area

99. Agroforestry competences and human resources needs in the Philippines 
100. CES/COS/CIS paradigms for compensation and rewards to enhance environmental Services

101. Case study approach to region-wide curriculum and teaching materials development in agroforestry education in Southeast Asia 

The World Agroforestry Centre is an autonomous, non-profit research organization whose vision is a rural transformation in the developing world where smallholder households strategically increase their use of trees in agricultural landscapes to improve their food security, nutrition, income, health, shelter, energy resources and environmental sustainability. The Centre generates science-base knowledge about the diverse role that trees play in agricultural landscapes, and uses its research to advance policies and practices that benefit the poor and the environment.

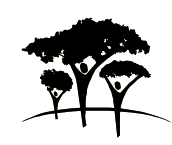

United Nations Avenue, Gigiri - PO Box 30677 - 00100 Nairobi, Kenya Tel: +254207224000 or via USA +1 6508336645 Fax: +254 207224001 or via USA +1 6508336646 Southeast Asia Regional Programme - Sindang Barang, Bogor 16680 PO Box161 Bogor 16001, Indonesia Tel: +62 251625415 - Fax: +62 251625416 www.worldagroforestry.org 